\title{
Classification of steppe vegetation in the eastern Pamir Alai and southwestern Tian-Shan Mountains (Tajikistan, Kyrgyzstan)
}

\author{
Arkadiusz Nowak*, Agnieszka Nobis, Sylwia Nowak \& Marcin Nobis
}

\begin{abstract}
Aims: To complete the syntaxonomical scheme for the steppe vegetation of the montane and alpine zones in the Pamir Alai and southwestern Tian-Shan Mountains in Tajikistan and Kyrgyzstan with some remarks on its environmental predictors. Location: Tajikistan and Kyrgyzstan. Methods: A total of 274 relevés were sampled in 2016-2017 using the seven-degree cover-abundance scale of Braun-Blanquet. They were classified with modified TWINSPAN with cut-off levels of $0 \%, 5 \%, 10 \%$ and $25 \%$ and total inertia as a measure of cluster heterogeneity. Diagnostic species were identified using the phi coefficient as a fidelity measure. Detrended correspondence analysis (DCA) and canonical correspondence analysis (CCA) were used to explore the relationships between groups in the dataset and to determine the environmental gradients that predict the species composition and distributional patterns of particular communities. Results: A total of 11 steppe communities were distinguished for the study area, grouped in five alliances and three orders. Seven of them are defined as new associations: Astragalo chomutowii-Stipetum subsessiliflorae, Stipetum bungeanae, Convolvuletum spiniferi, Stipo magnificae-Otostegietum olgae, Littledaleo alaicae-Stipetum trichoidis, Helictotricho fedtschenkoi-Stipetum kirghisori and Astragalo lithophili-Stipetum zalesskii. The communities belong to the Piptathero gracilis-Artemision brevifoliae (high-altitude, cold arid plateaus) and Ajanio-Cleistogenenion songoricae (alpine arid mountainous areas; both Ajanio-Cleistogenetea songoricae), the Poo bulbosae-Artemision persicae related to warm montane-subalpine belts of the southern part of Middle Asia (Astragalo microcephali-Brometea tomentelli, Carici stenophylloidis-Stipetalia arabicae) and the Stipion krylovii, typical steppes in semi-arid subalpine and alpine belts (Stipetalia krylovii, Cleistogeneta squarrosae). Within the Stipetalia krylovii, the TWINSPAN revealed a second unit at alliance level next to the Stipion krylovii, with currently only one association, but due to the limited amount of data we refrained from making a formal description. The main factors responsible for the species composition of the researched vegetation were altitude, content of organic top soil, and longitudinal position. Conclusions: We have completed the vegetation survey of the steppes in the middle and western part of Central Asia and have fostered the progress in finding the borderland between the steppes of the western Asiatic and central Asiatic subregions. This geographic transition corresponds to a syntaxanomic division between the classes of Astragalo microcephali-Brometea tomentelli Quézel 1973 and Cleistogenetea squarrosae Mirkin et al. ex Korotkov et al. 1991.
\end{abstract}

Keywords: Ajanio-Cleistogenetea songoricae; alpine vegetation; Astragalo microcephali-Brometea tomentelli; Cleistogenetea squarrosae; grassland; Middle Asia; plant community; steppe; Stipa; syntaxonomy; vegetation.

Taxonomic references: For vascular plants Cherepanov (1995) but for Bromus The Plant List (2013) Version 1.1. http://www.theplantlist.org/; for syntaxa Ermakov (2012), Gadghiev et al. (2002) and Eberhardt (2004).

Abbreviations: $\mathrm{CCA}$ = canonical correspondence analysis, $\mathrm{DCA}=$ detrended correspondence analysis; rel. = relevé.

Submitted: 20 September 2017; first decision: 4 December 2017; accepted: 24 April 2018

Co-ordinating Editor: Jürgen Dengler

*Corresponding author's address: Botanical Garden, Center for Biological Diversity Conservation, Polish Academy of Sciences, Prawdziwka 2, 02-976 Warszawa, Poland; anowak@uni.opole.pl. Complete addresses of all authors can be found at the bottom of the paper. 


\section{Introduction}

Steppe covers an extensive area in Eurasia and stretches between China in the east, southern Siberia, Kazakhstan, through Central and western Asia, and Eastern Europe up to Hungary and Romania in the west. This vegetation type occurs in areas with a continental climate, with temperatures up to $45{ }^{\circ} \mathrm{C}$ in summer and $-55{ }^{\circ} \mathrm{C}$ in winter and relatively low precipitation $(250-450 \mathrm{~mm} / \mathrm{yr}) \mathrm{com}-$ bined with high evapotranspiration (Lavrenko et al. 1991; Werger \& van Staalduinen 2012). Steppe coenoses are one of the most floristically diverse vegetation types that occur both in the lowland and in the montane areas of temperate Eurasia (Dengler et al. 2014; Willner et al. 2016). In many areas of Central Asia (mainly Mongolia, northwestern China and eastern Kazakhstan), steppe is the dominant vegetation and has attracted attention of botanists in their research efforts for decades (Lavrenko et al. 1991; Hilbig 1995; Borchardt et al. 2011; Miehe et al. 2011; Taft et al. 2011; Rachkovskaya \& Bragina 2012; Smelansky \& Tishkov 2012). Notwithstanding the aforementioned work, in Middle Asia the first research regarding the diversity of steppe plant communities and their detailed analysis was published very recently (Nowak et al. 2016; Bragina et al. 2018).

A consistent and comprehensive large-scale classification of vegetation units is an indispensable tool in ecological studies (e.g. diversity comparisons at community and ecosystem levels), for vegetation monitoring, implementing effective management and for developing conservation strategies and legislation (Dengler et al. 2008). Unfortunately, despite extraordinary richness, an overview of the grassland vegetation of Tajikistan or the entire Middle Asia, with detailed information on their species composition, physiognomic structure, distribution and coverage, has never been compiled. This is probably due to the fact that at the beginning of the field exploration of this vast and hardly accessible area, only a few botanical expeditions have been conducted with the main focus on taxonomical studies (e.g. Lipskyi 1903). The first insights into the classification of steppe vegetation were provided by Russian botanists, who used the dominant or physiognomic approach (e.g. Stanyukovich 1982). This physiognomic or dominant species approach provided the first classification of the Middle Asian steppes which were considered as composed of a) temperate- and drought-tolerant, rich forb-feather grass steppes on chernozem (with Festuca valesiaca and Stipa zalesskii as dominants), b) temperate dry bunchgrass steppes on dark chestnut soils (with Festuca valesiaca, Koeleria cristata, Stipa lessingiana, S. capillata), c) dry xerophytic forb-bunchgrass steppes on chestnut soils (with Festuca valesiaca, Galatella divaricata, Phlomoides agraria and Stipa lessingiana), d) desert-sagebrushbunchgrass steppes on light chestnut soils (with Artemisia lerchiana, A. semiarida, Festuca valesiaca, Stipa lessin- giana and S. sareptana); within the desert steppes: e) steppes with Anabasis salsa, Salsola arbusculiformis, $\mathrm{Na}$ nophyton erinaceum, Salsola orientalis, f) steppes with Salsola gemmascens, Artemisia kemrudica, Carex physodes, Salsola laricifolia and Artemisia terrae-albae, and g) steppes of submountain deserts with Bromus danthoniae, B. tectorum, Poa bulbosa and Carex pachystilis (Korovin 1962; Ovchinnikov 1971; Stanyukovich 1982; Lavrenko et al. 1991; Agakhanjanz \& Breckle 2003; Rachkovskaya et al. 2003; Rachkovskaya \& Bragina 2012). In the meantime, there were some attempts to classify the Asian steppes with the use of the classical phytosociological approach for establishing the hierarchical syntaxonomical system. The most comprehensive proposal was given by Gadghiev et al. (2002). They classified the steppe vegetation into three main syntaxa: AjanioCleistogenetea songoricae Mirkin et al. 1988 (syn. Stipetea glareosae-gobicae Hilbig 2000), Cleistogenetea squarrosae Mirkin et al. ex Korotkov 1991 (syn. Agropyretea cristati Hilbig et Korolyuk 2000) and Festuco-Brometea Br.Bl. et Tx. ex Sóo 1947. The dry mountain steppes were also phytosociologically explored in the area of northern Pakistan in the Hindu Kush, Karakorum and Ladakh (Eberhardt 2004; Peer et al. 2007). Several plant communities at the ranks of alliances, suballiances and association were proposed for the various semi-deserts, steppeshrubs and arid steppes of this area.

Recent studies have focused on the classification of the feather-grass steppes of western Pamir Alai (Nowak et al. 2016). Due to their floristic composition and phytogeographical distinctiveness, these communities were assigned to the Poo bulbosae-Artemision persicae and to the provisional order Carici stenophylloidis-Stipetalia arabicae. Because of the differences in terms of climatic conditions and physiognomy, and of the scarcity of available data, they were provisionally included in the Irano-Turanian class Astragalo microcephali-Brometea tomentelli Quézel 1973.

Middle Asia is a region located in the landlocked, central part of the Asian continent and comprises Kyrgyzstan, Tajikistan, Uzbekistan, Turkmenistan, southern Kazakhstan, western China and northern Afghanistan. Its southern and eastern parts encompass the high mountains of the Pamir Alai and Tian-Shan (Fig. 1). According to the ten-volume study of the flora of the former Soviet part of the Middle Asia (Conspectus Florae Asiae Mediae; Kovalevskaya 1968), more than 8,000 vascular plant species are known from this region. Owing to the diverse relief, geomorphology and extremely variable microclimatic condition, the region harbors a high number of endemic species. In Tajikistan alone, ca. $30 \%$ of the entire flora of vascular plants are accepted as endemics of the country, with more than 360 growing in steppe vegetation (Nowak et al. 2011). Due to this extraordinary richness, the mountains of Middle Asia have been recognised as one of the 35 hotspots of biodiversity (Mittermeier et al. 2006). At the same time, the vegetation of this region is 


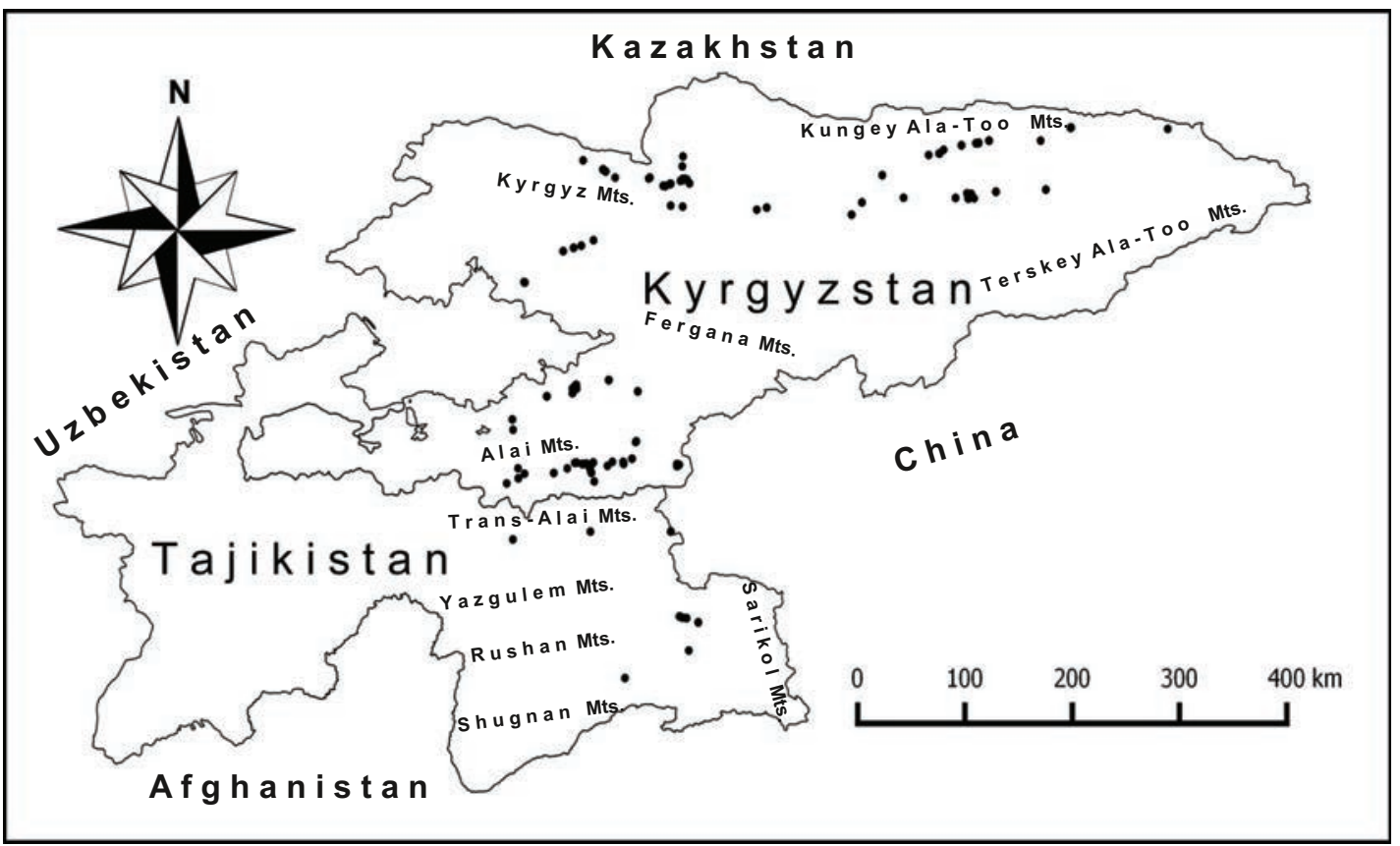

Fig. 1. The study area with the borders of Tajikistan and Kyrgyzstan and the main mountain ranges. The sampling sites are indicated by black dots.

exposed to the high risks linked to climate change (Baettig et al. 2007) with the near-lowest adaptive capacity to climate instability (Fay \& Patel 2008). Recent publications on conservation issues highlighted the need for a better understanding of the vegetation and the ecological processes in this region (Giam et al. 2010).

This paper is a contribution to a research devoted to grassland diversity in Middle Asia that deals with the classification of feather-grass steppes in western Pamir Alai. It refers to unexplored areas of the eastern Pamir Alai and southwestern Tian-Shan ranges, but still with the focus on the steppes of the montane and alpine belts.

The main aims of our phytosociological survey were to address the following questions: (1) What is the distribution and classification of steppe vegetation of montane and alpine zones in the eastern Pamir Alai and southwestern Tian-Shan Mts.? (2) What is the species composition and physiognomy of the distinguished plant communities? (3) What are the most important environmental variables that influence the species composition of the plant communities occurring in the studied area?

\section{Study area}

The vegetation survey was conducted in the central part of Middle Asia (southern and eastern Kyrgyzstan and eastern Tajikistan), stretching over ca. 150,000 km² (Fig. 1). The study region included the southwestern ranges of the Tian-Shan and the eastern part of the Pamir
Alai Mts. It encompasses the colline (around Fergana Basin; up to ca. $1500 \mathrm{~m}$ a.s.l.), montane (1500-2200 m a.s.l.) and alpine belts (2200-3500 m a.s.l.; Stanyukovich 1982). The mountainous landscape and the long human land use, particularly grazing by horses and sheep, created a suitable habitat for different types of grassland communities. In this area, steppes are the most important grass vegetation type in intermediate altitudes, followed by pastures in the alpine belt, meadows in the river valleys and xerophytic meadows on the southern slopes of the colline belt. Degraded plant communities, as reported from Mongolia and Kazakhstan, being considered as poor pasture, are rare and occur only locally, under high grazing pressure (Cheng et al. 2008; Rachkovskaya \& Bragina 2012). Steppes cover the undulating slopes in the colline, montane and alpine belts, but also the terraces and floodplains of the alpine river valleys as well as colluvial and diluvial deposits in higher elevations. The studied slopes differ in terms of aspect, inclination, bedrock type and altitude. The vegetation plots were located between 653 and $4092 \mathrm{~m}$ a.s.l. (mean $2225 \mathrm{~m}$ a.s.l.).

The climatic conditions of the region are complex due to variable altitudes and orographic effects. In addition, the region is at the intersection of the temperate and Irano-Turanian bioclimate (Djamali et al. 2012). Some basic climatic features are presented in Table 1 according to Latipova (1968), Narzikulov \& Stanyukovich (1968) and Safarov (2003).

However, strong differences in topography and altitude cause local deviations from the main bioclimatic 
Table 1. Climatic characterisation of the four main zones in the study area. $P=$ precipitation; $T=$ temperature.

\begin{tabular}{|c|c|c|c|c|}
\hline Climate type & $\begin{array}{l}\text { Warm, dry, } \\
\text { continental }\end{array}$ & $\begin{array}{l}\text { Warm humid, } \\
\text { continental }\end{array}$ & Cold semi-arid & Cold deserts \\
\hline Yearly average $P$ [mm] & $200-250$ & $500-1000$ & $200-400$ & $<100$ \\
\hline Peak of P [mm] & March & March - April & April - May & May, August \\
\hline $\begin{array}{l}\text { Average } P \text { in summer month } \\
{[\mathrm{mm}]}\end{array}$ & $0-10$ & $3-10$ & $15-25$ & $8-10$ \\
\hline Mean $\mathrm{T}$ in April $\left[{ }^{\circ} \mathrm{C}\right]$ & $16-20$ & $5-12$ & $0-5$ & $-5-2$ \\
\hline Average $\mathrm{T}$ in June $\left[{ }^{\circ} \mathrm{C}\right]$ & $32-34$ & $10-22$ & $12-17$ & 10 \\
\hline Average yearly $\mathrm{T}\left[{ }^{\circ} \mathrm{C}\right]$ & $20-24$ & $8-15$ & ca. 0.5 & ca. 0 \\
\hline Altitudinal zonation & lowlands - foothills & montane - alpine & colline - alpine & subalpine - alpine \\
\hline Main areas & Fergana Basin & $\begin{array}{l}\text { Tian-Shan and } \\
\text { Pamir Alai ranges }\end{array}$ & $\begin{array}{l}\text { Issyk-Kul basin, } \\
\text { Alai Valley }\end{array}$ & $\begin{array}{l}\text { Alai Valley, Eastern } \\
\text { Pamir, Balykchy }\end{array}$ \\
\hline
\end{tabular}

trends. These climatic and bioclimatic terms determine the treeless vegetation as dominant in the colline and montane belts and are responsible for the extent of meadows and pastures in the alpine belt.

\section{Methods}

The phytosociological studies were carried in 20152016. Altogether, 274 relevés were collected and added to the existing database for western Pamir Alai to obtain an insight into the differences between the basic groups of steppe vegetation. All relevés are stored in Vegetation of Middle Asia Database (GIVID ID: AS-00-003; Nowak et al. 2017). The size of each vegetation plot was $20 \mathrm{~m}^{2}(4 \mathrm{~m} \times 5 \mathrm{~m})$. All vascular plant species were recorded using the seven-degree cover-abundance scale of Braun-Blanquet (Westhoff \& van der Maarel 1973). Bryophytes and lichens were not recorded because of their negligible abundance and importance in the studied vegetation. The survey covered a broad range of habitats in relation to altitudinal range, aspect and inclination. The geographical coordinates were measured for each plot with the help of a GPSMAP 60CSx device

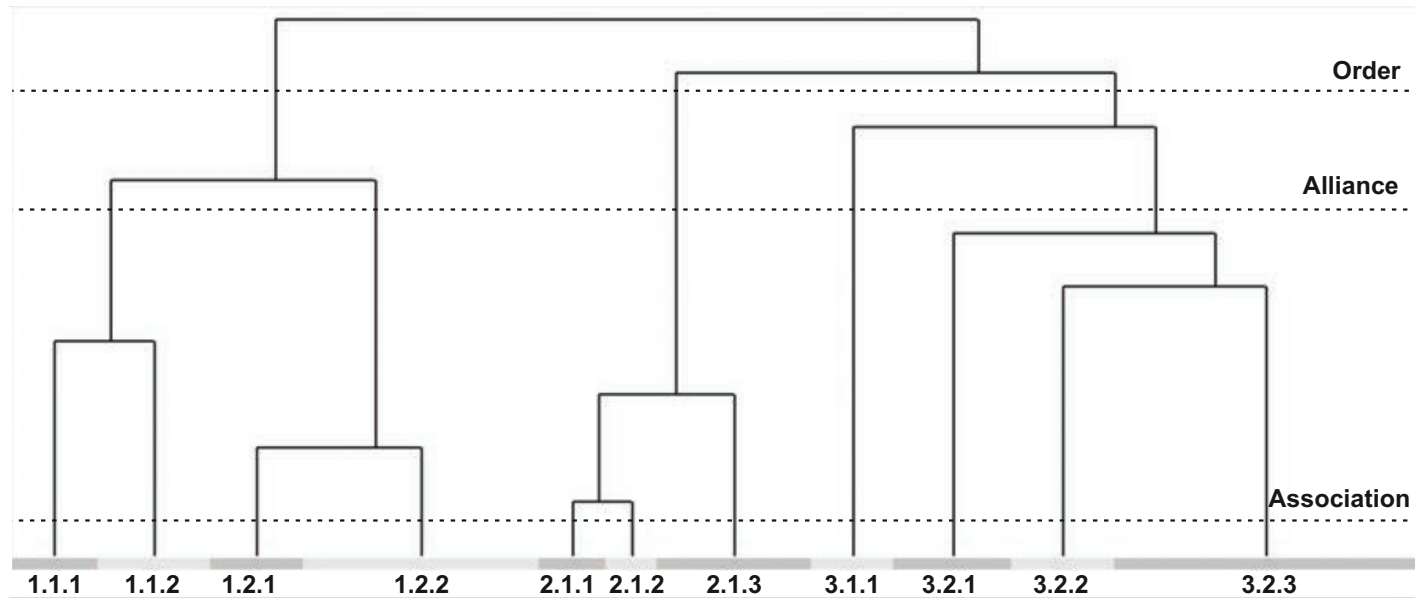

Fig. 2. TWINSPAN classification diagram for the whole data set of 274 relevés. The figures at the bottom are the cluster numbers, while the width of the bars is proportional to the number of releves originally assigned to the clusters. The assignment of phytosociological ranks is indicated by horizontal lines. 1.1.1 - Serratula procumbens-Stipa caucasica subsp. desertorum community; 1.1.2 - Astragalo chomutowii-Stipetum subsessiliflorae; 1.2.1 - Stipa krylovii-Stipa breviflora community; 1.2 .2 - Stipetum bungeanae; 2.1.1 - Convolvuletum spiniferi; 2.1.2 - Elytrigia trichophora-Linum corymbulosum community; 2.1 .3 - Stipo magnificae-Otostegietum olgae, 3.1.1 - Littledaleo alaicae-Stipetum trichoidis; 3.2.1 - Astracantha pterocephalaDracocephalum bipinnatum community; 3.2.2 - Helictotricho fedtschenkoi-Stipetum kirghisori; 3.2.3 - Astragalo lithophiliStipetum zalesskii. 
with an accuracy of $\pm 5 \mathrm{~m}$, using the WGS84 coordinate system.

Data were stored in the TURBOVEG (Hennekens \& Schaminée 2001) and analysed in JUICE (Tichý 2002). Modified TWINSPAN (Hill 1979; Roleček et al. 2009; Fig. 2) was used to classify plant communities based on species composition. The cover-abundance scale was transformed using the four-step interval scale with cutoff levels at $0 \%, 5 \%, 10 \%$ and $25 \%$. Total inertia was used as a measure of cluster heterogeneity (Roleček et al. 2009). Taxa identified only at the genus level were omitted during the analysis. Diagnostic species were identified using the phi coefficient as a fidelity measure (Chytrý \& Tichy 2003). Group size was standardised, and the Fisher exact test $(p<0.05)$ was applied. Species with a phi coefficient higher than 0.40 were considered diagnostic for a particular cluster. Diagnostic taxa for alliances were defined as those with a phi coefficient $\geq 0.15$ in at least two clusters within this alliance. Species with a higher frequency than $50 \%$ were defined as constant and those with a maximum cover value exceeding $30 \%$ as the dominant species of an individual cluster (plant community).
For translation of the TWINSPAN results into phytosociological associations, we chose the highest division that still yielded floristically well characterized terminal clusters with their own diagnostic species (Dengler et al. 2005; Michl et al. 2010). These terminal clusters were considered as associations or plant communities depending on the geographical range and certainty of taxonomical status of the diagnostic species. During the division the habitat profile and authors' field experience were used as to find the comprehensive and ecologically interpretable results of classification.

To check the floristic-sociological classification and to highlight the relationships between relevés and species, detrended correspondence analyses (DCAs) were performed (no downweighting of rare species, response data were log-transformed; Fig. 3). Species cover values of the 7-degree Braun-Blanquet scale were transformed to a percentage scale $(r,+, 1,2,3,4,5$ to $0.1,1,5,15,37.5,62.5$ and 87.5 respectively). The relationships between plant communities and environmental predictors: longitude, latitude, altitude, inclination $\left({ }^{\circ}\right)$, aspect, percentage of soil cover in a plot and rock debris size as a subset of the most

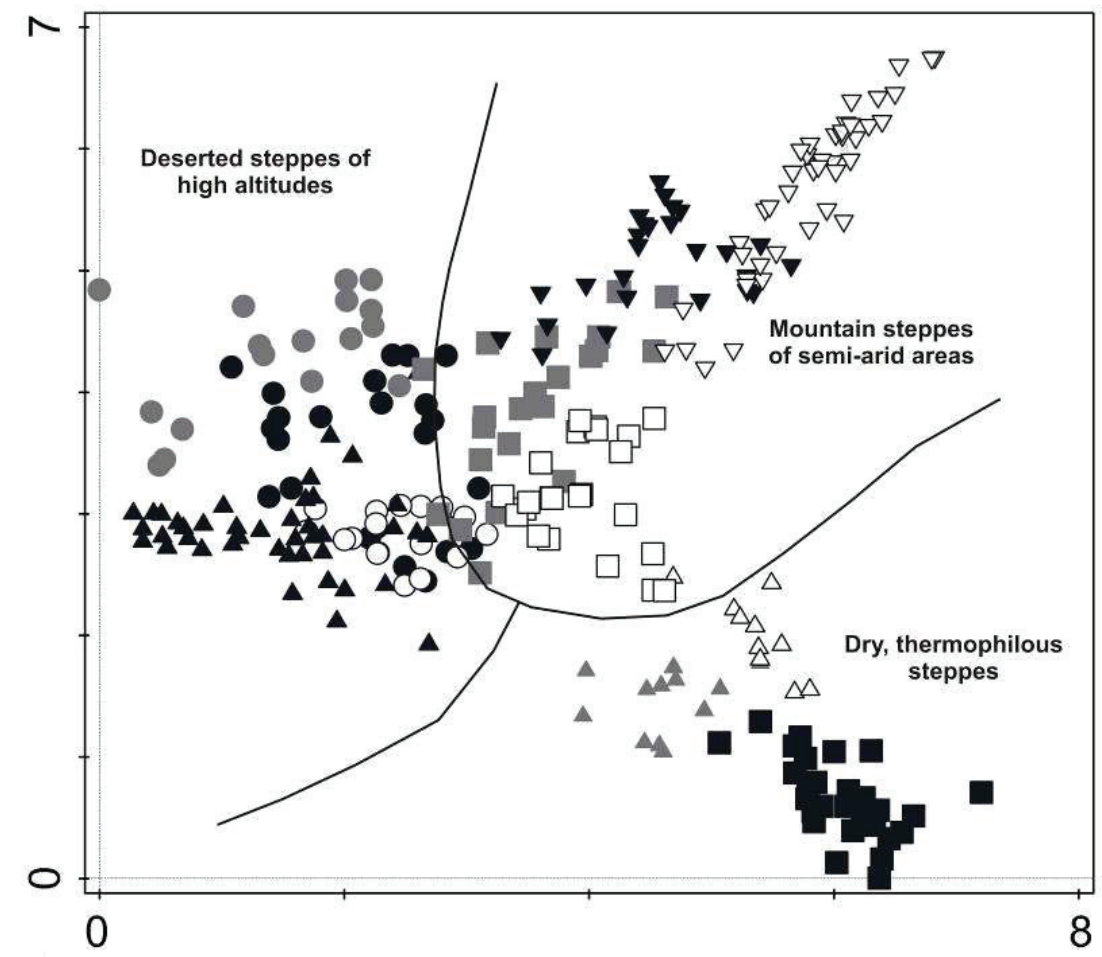

- Serratula procumbens-Stipa caucasica subsp. desertorum community (1.1.1), Astragalo chomutowiiStipetum subsessiliflorae (1.1.2), O Stipa krylovii-Stipa breviflora community (1.2.1), $\boldsymbol{\Delta}$ Stipetum bungeanae

(1.2.2), $\Delta$ Convolvuletum spiniferi (2.1.1), Elytrigia trichophora-Linum corymbulosum community (2.1.2),

Stipo magnificae-Otostegietum olgae (2.1.3), Littledaleo alaicae-Stipetum trichoidis (3.1.1), $\square$ Astracantha pterocephala-Dracocephaletum bipinnatum community (3.2.1), $\boldsymbol{\nabla}$ Helictotricho fedtschenkoi-Stipetum kirghisori (3.2.2), $\nabla$ Astragalo lithophili-Stipetum zalesskii (3.2.3).

Fig. 3. DCA ordination for all relevés of steppe communities in eastern Pamir and southwestern Tian-Shan ( $N=274)$. Rare species were not downweighted, response data were log transformed. The 7-degree Braun-Blanquet scale ( $r$, +, 1, 2, 3, 4, 5) was transformed to a percentage cover scale $(0.1,1,5,15,37.5,62.5,87.5)$. The eigenvalues and lengths of gradients were $0.78,7.21$ (Axis 1) and $0.74,6.75$ (Axis 2), respectively. 
important field determinants of species composition used as explanatory variables were analysed with canonical correspondence analysis (CCA). Aspect was transformed along the N-S line, folding $0-360^{\circ}$ to $0-180^{\circ}$ such that $\mathrm{NE}=\mathrm{NW}, \mathrm{SE}=\mathrm{SW}$, etc. Vegetation cover and species richness were passively projected post-hoc onto the ordination. Detrending by segments was used in the DCA, inter-species distance and Hill's scaling were applied in the CCA. Species cover data were logarithmically transformed in both analyses. A standard Monte Carlo permutation test with 499 unrestricted permutations were conducted to identify the significance of the effects of environmental variables on the species composition of the analysed samples. CANOCO for Windows 5 was used for ordination (ter Braak \& Šmilauer 2002). The species composition data showed a clear unimodal response, with a total gradient length of ca. 7.2. The means of the measured environmental and vegetation parameters were determined (altitude, inclination, species richness per plot, vegetation cover, aspect, rock debris size and percentage of soil cover) for all the associations.

In the analytic tables (Supplements S1-S3), species frequencies were given in percentage values. Fidelity (phi coefficient) and percentage frequency for diagnostic and frequent taxa are shown in a synoptic table (Table 2). Only species with a phi coefficient $\geq 0.40$ and frequency $\geq 20 \%$ are shown. For descriptions of new associations, the International Code of Phytosociological Nomenclature (Weber et al. 2000) was adhered to. The type relevés are given in the description of the discussed syntaxa. All the mentioned syntaxa were arranged into a syntaxonomic overview at the beginning of the description in the Results section. When establishing a new association, we follow the recommendation 7A of the ICPN (Weber et al. 2007). That is, we left the community rankless when the diagnostic species exhibit a fairly wide geographical range and occur in the limits of their distribution within the study area. Furthermore, if the taxonomical position of the diagnostic species for the community was unresolved or vague, we also decided to define this type of vegetation as rankless. Additionally, we refrained from defining the association when the species with the highest fidelity were observed as having wider ecological amplitude in the field studies, but not documented in the data set. As the most significant habitat attributes may be considered the presence of a soil layer, altitude, total vegetation cover and slope inclination.

\section{Results}

\section{General floristic characteristics and relations between the identified plant communities}

The total number of taxa recorded in the whole data set (274 relevés) was 543, with 503 vascular herb species (127 annuals and 376 perennials), 14 shrubs (Cerasus verrucosa, Colutea paulsenii, Lycium ruthenicum, Restella albertii, Zygophyllum atriplicoides, and species from the genera Atraphaxis, Caragana, Ephedra and Salsola). Additionally, 24 dwarf shrubs were noted, with Artemisia kuschakeviczii, A. maracandica, A. rutifolia, A. skorniakowii, Krascheninnikovia ceratoides and Silene brabuica as the most frequent taxa. Only 21 species achieved a frequency higher than $10 \%$ in whole data sets and 94 exceeded a $5 \%$ frequency. The group of species with the highest frequencies includes the following: Festuca valesiaca (25.2\% frequency), Stipa capillata and Carex turkestanica (18.9\%), Artemisia kuschakeviczii (18.6\%), Stipa cancasica (18.2\%), Centaurea squarrosa (16.8\%), Krascheninnikovia ceratoides (15.7\%) and Erysimum diffusum $(14.2 \%)$. The core group of species that contribute to the data set are plants adapted to extensive grazing. The contribution of plants that have their ecological optimum in other vegetation types, mainly in dry meadows, screes, rock habitats, ruderal and segetal vegetation, xerophytic shrubs, tall forbs, alpine cushion communities, humid pastures, semi-deserts or even deserts, was negligible.

Our correspondence analysis revealed that plant communities differed among study regions due to the large and climatically different research area. Three main groups can be distinguished: mountain steppes; high-altitude deserted steppes of arid zones; and thermophilous steppes (Fig. 3). The first group is characterised by the considerable soil cover and flat terrain. The second, located on the upper left corner of the diagram, includes steppes of the arid areas of the eastern Issyk-Kul basin and the highly elevated area in the Alai Valley and eastern Pamir. The last group, shown on the bottom right part of the graph, encompasses xerothermophilous steppes, with the distributional optimum in the montane belt. They occupy the lowest locations in the study area, on slopes with a southern exposure. These steppes are composed of many species and have a high herb layer cover.

\section{Classification of the vegetation units}

Our classification analysis detected 11 plant communities that were well-defined in terms of species composition. For the superior syntaxonomic ranks, we selected levels within the cluster tree that yielded floristically unique and ecologically interpretable units. We interpreted the three-cluster level as orders, and the five-cluster level as alliances. In this way, each syntaxonomic level corresponded to a horizontal plane in the dendrogram (Fig. 2). One cluster on the alliance level was left without formal definition and classification as there was no sufficient comparative data from the surrounding areas that can justify and legitimate such assignment. The association of Littledaleo alaicae-Stipetum trichoidis possibly belonged to unknown vegetation unit with the Tibetan range, but 


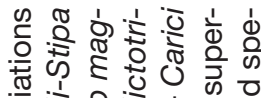

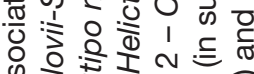

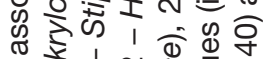

空

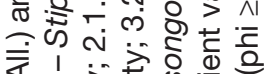

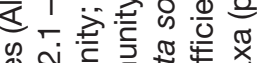

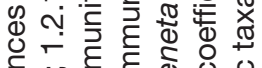

完

\%

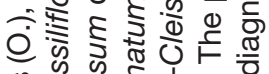

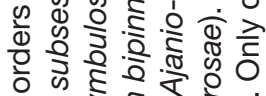

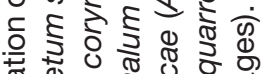

要

ब.

ग)

范

응 है ह

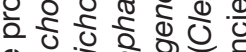

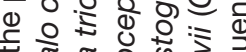

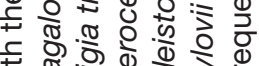

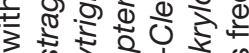

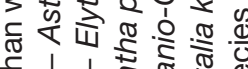

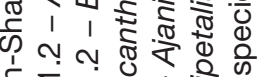

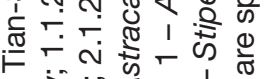

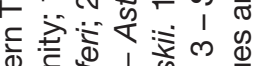

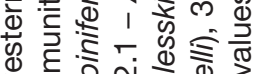

गे है

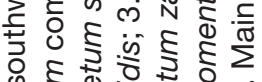

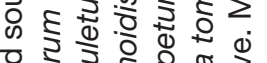

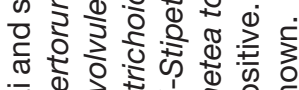

西要

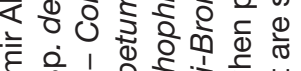

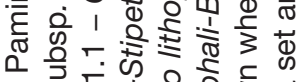

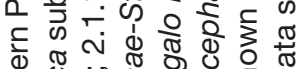

过

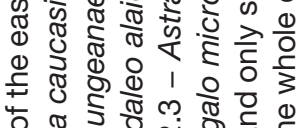

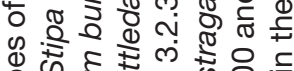

क क ह

क्ष

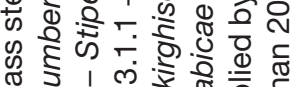

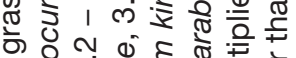

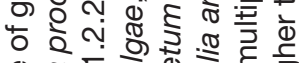

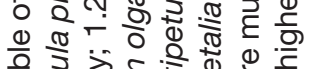

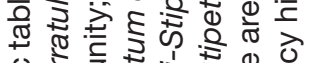

는

응

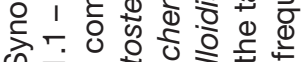

की

ส่-

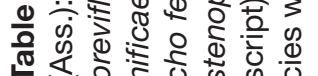

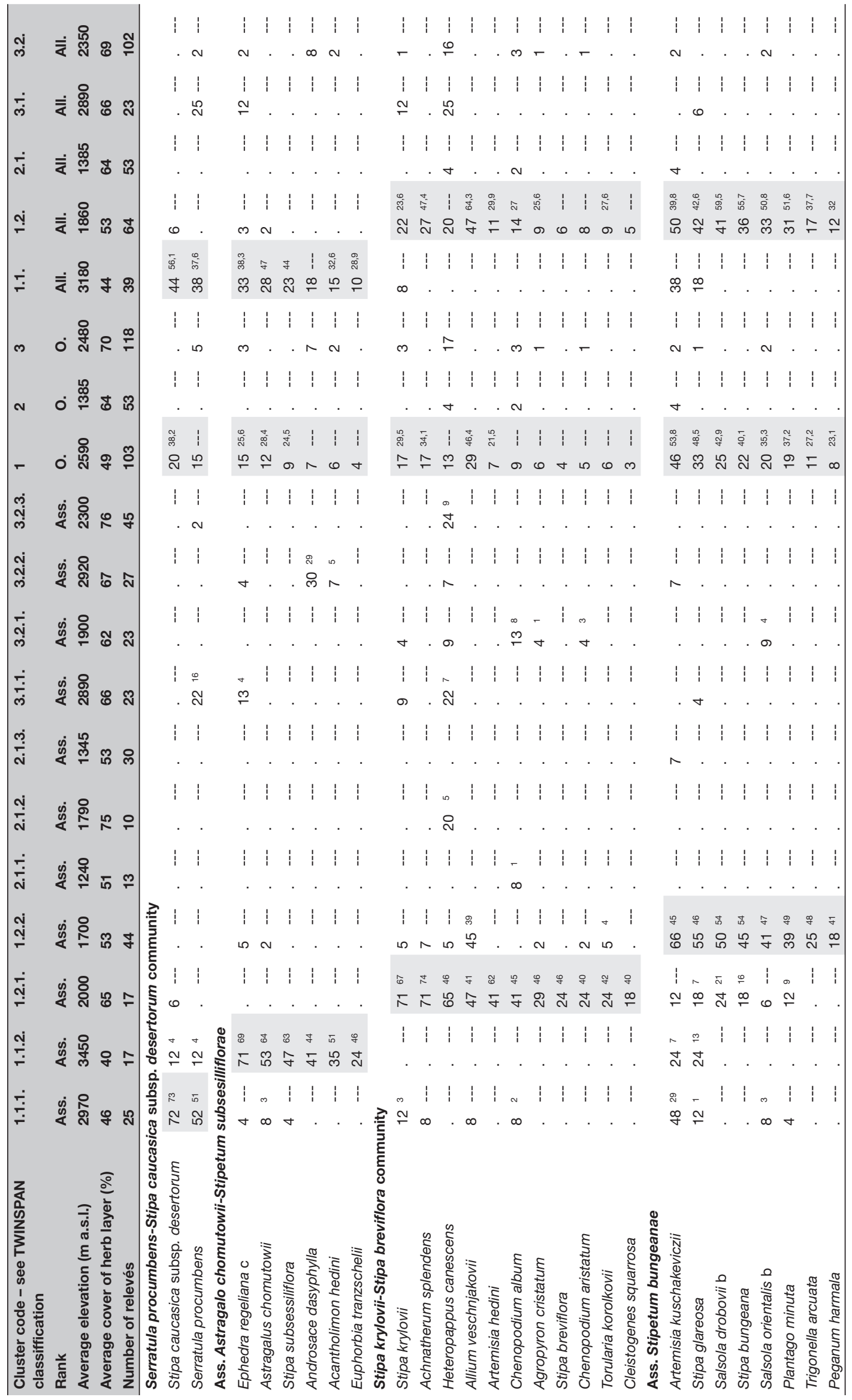




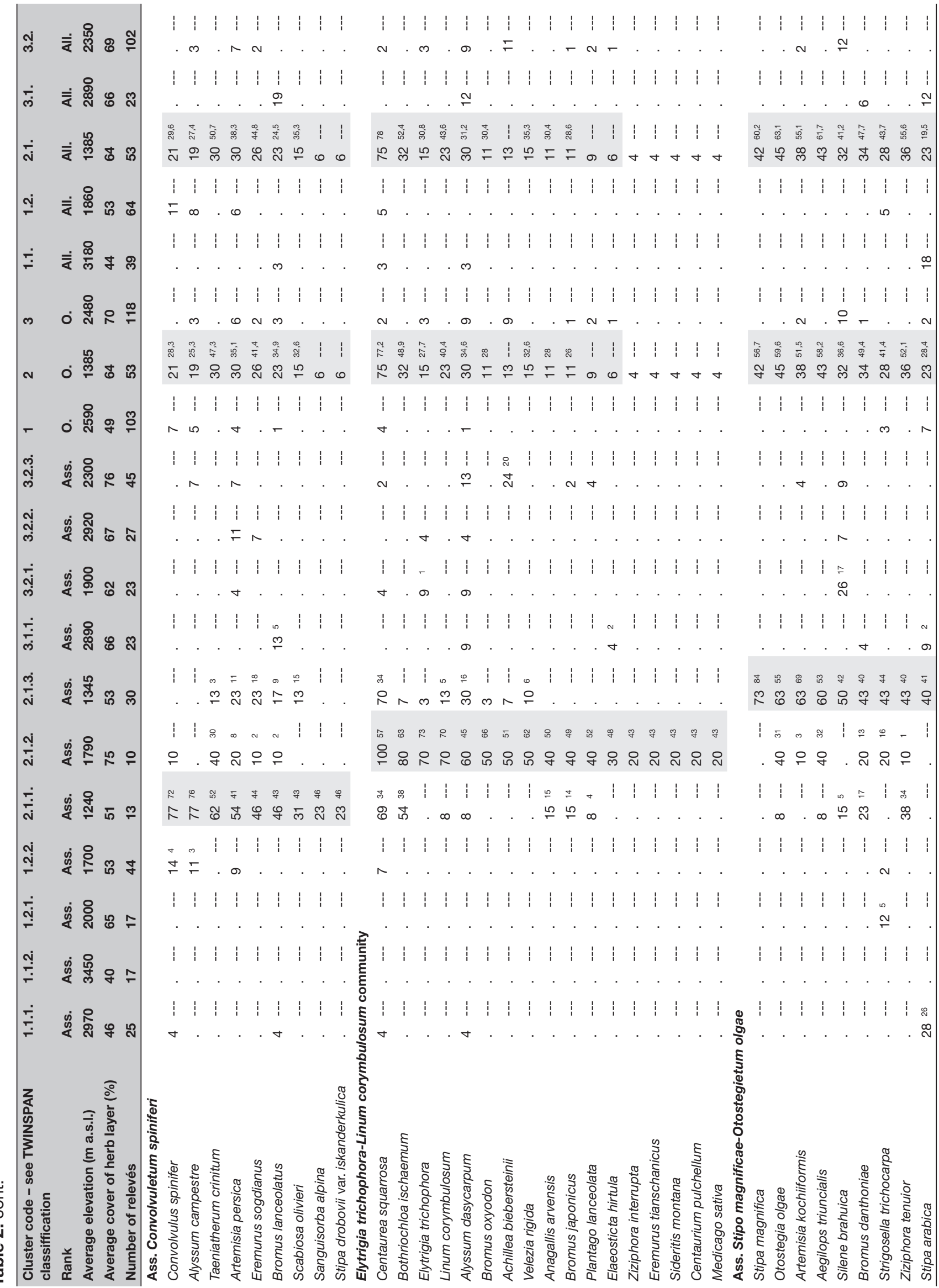




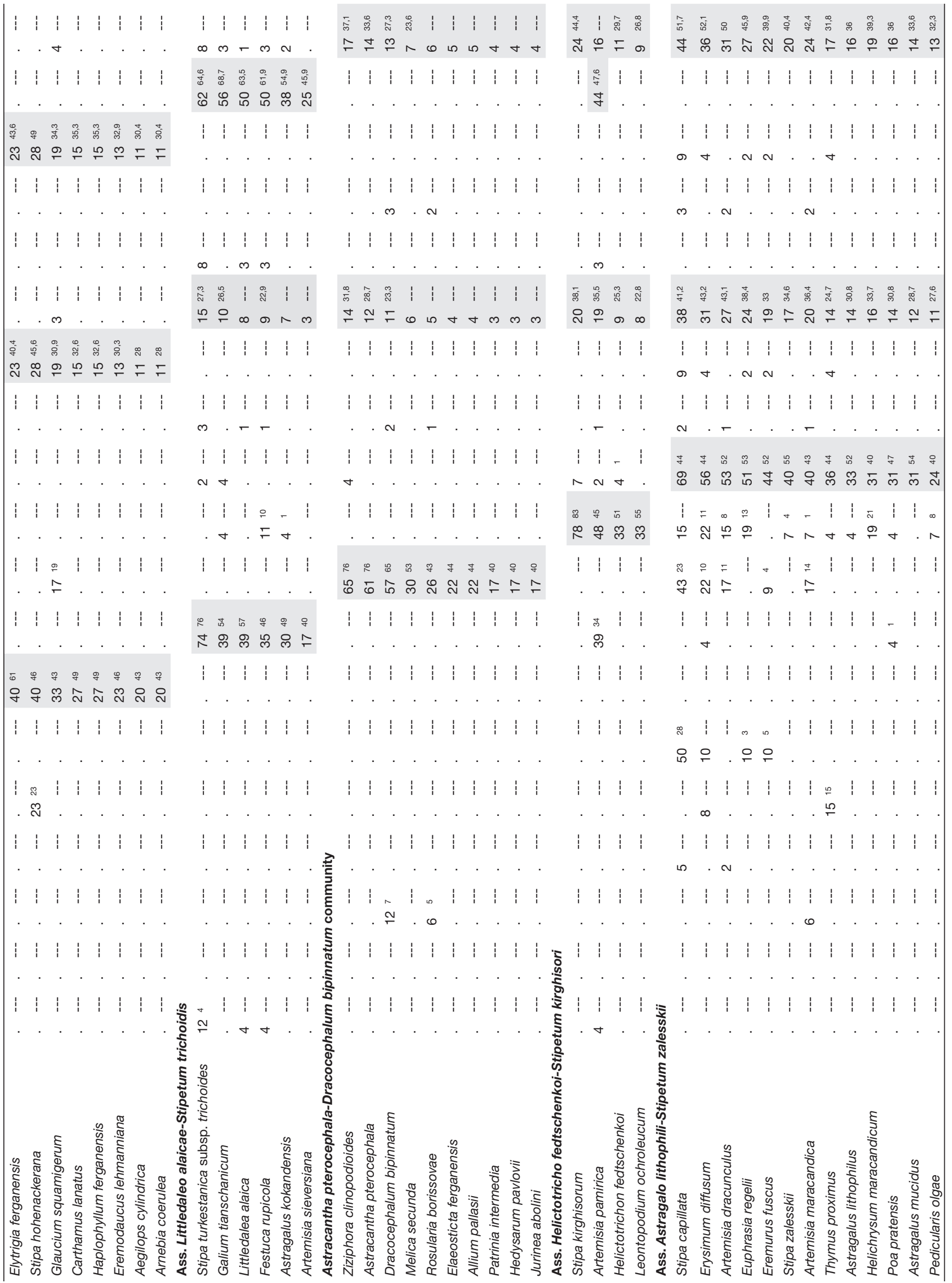




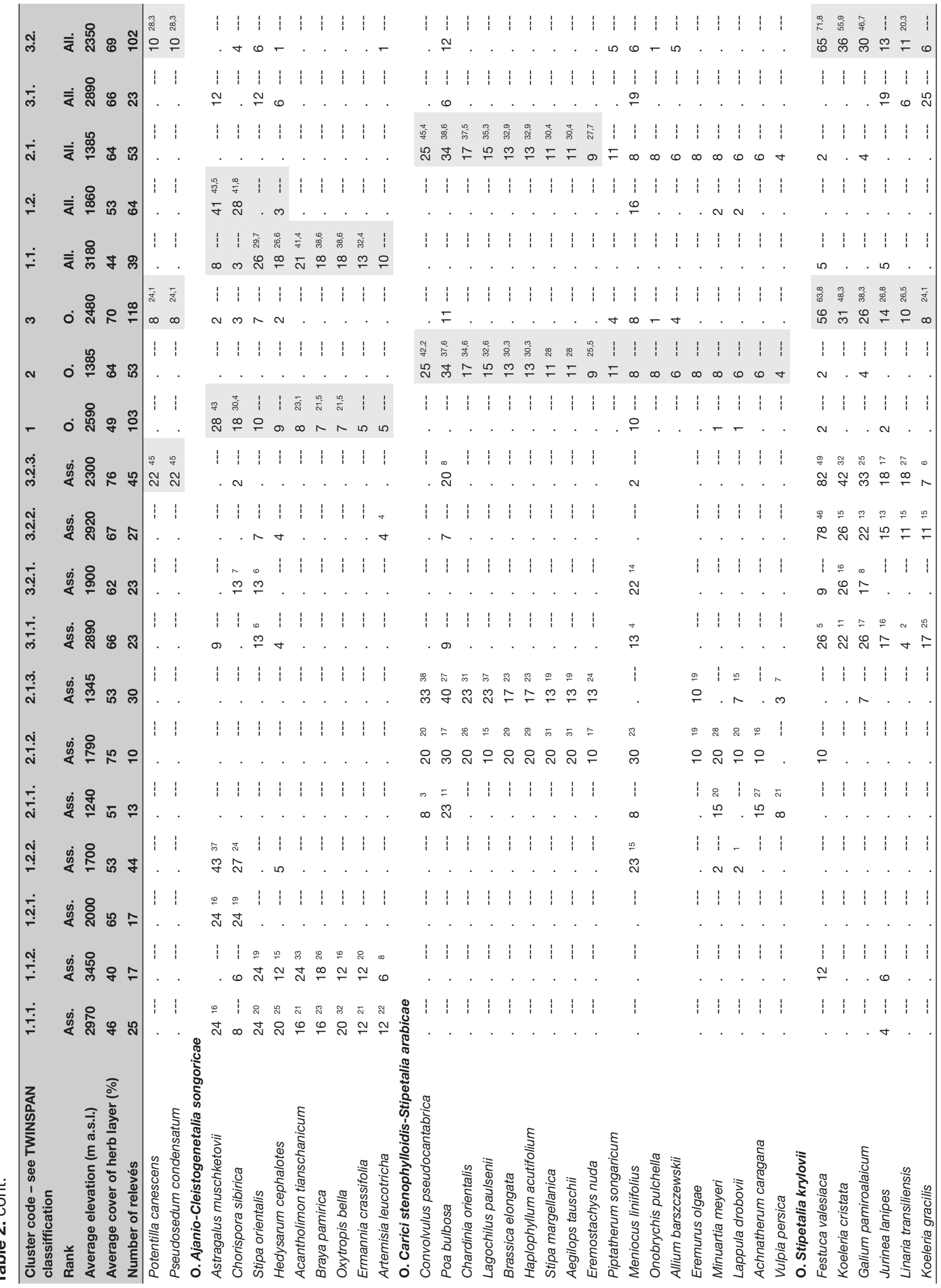




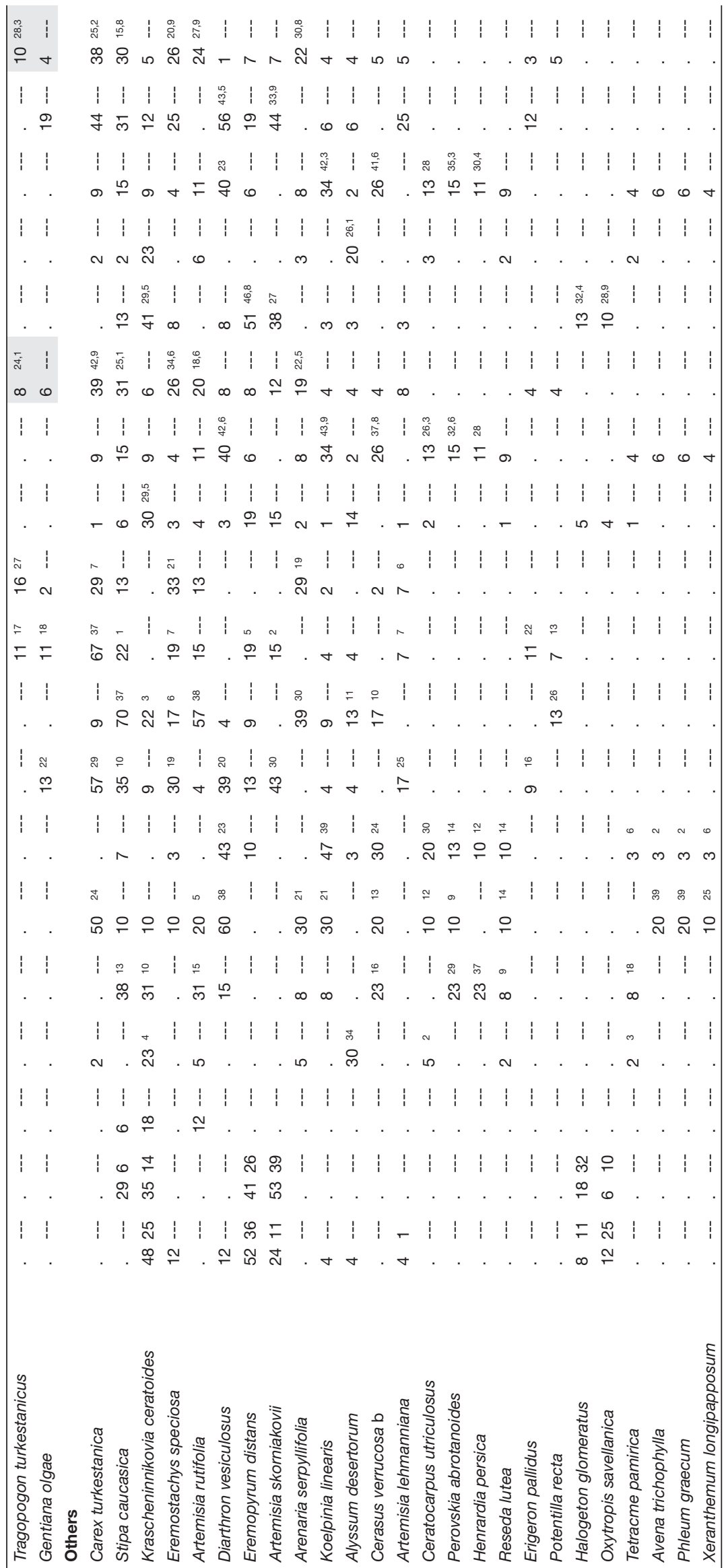



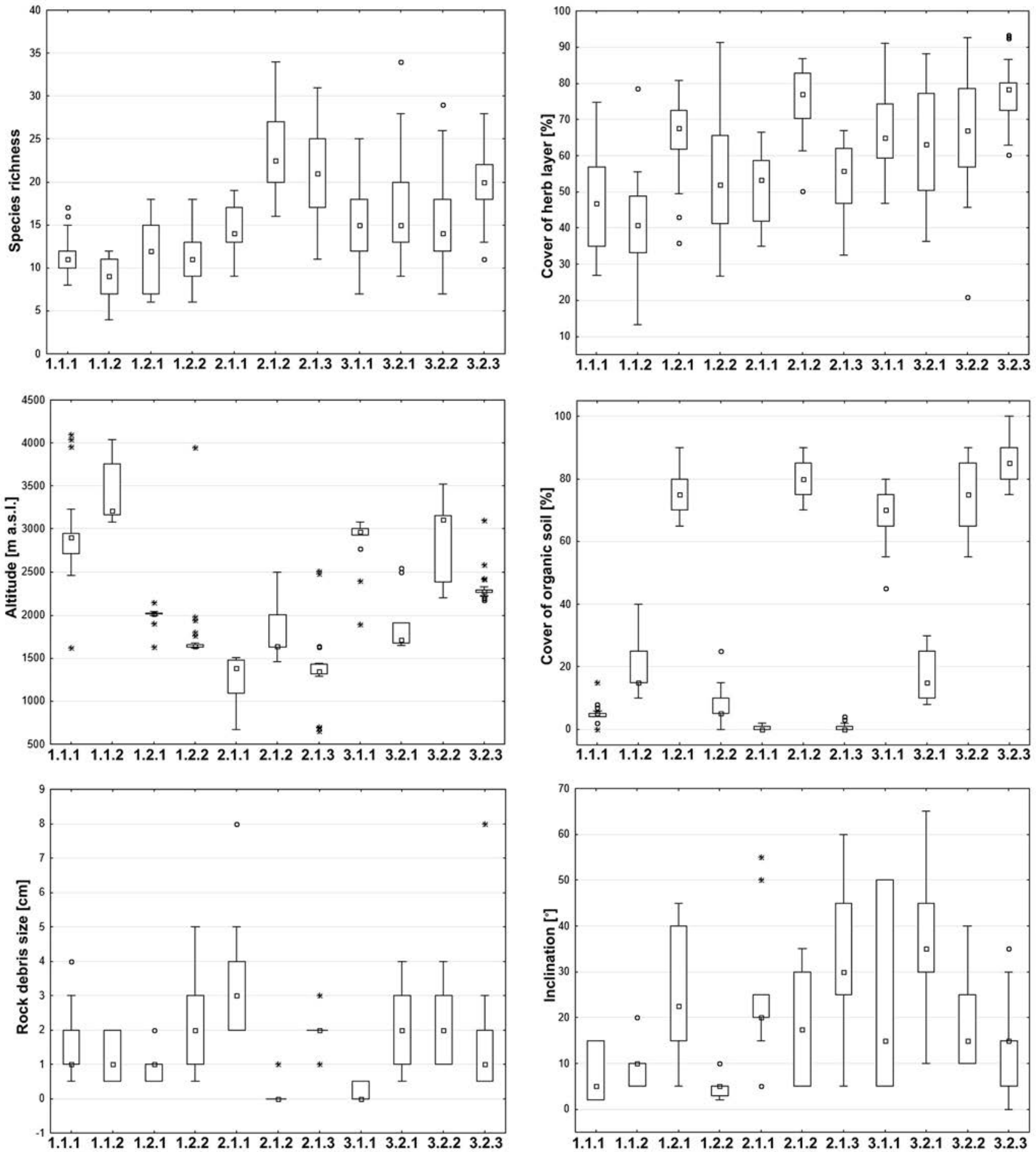

Fig. 4. Box-whisker plots for the number of species per plot (Vascular plant species richness on $20 \mathrm{~m}^{2}$ ), cover values of herb layer, altitudinal distribution, cover of organic soil, size of rock debris and the slope inclinations of the studied associations. Abbreviations of plant communities follow Fig. 2.

still revealed some floristic and habitat similarities with other plant communities of Stipion krylovii. As our research was pionieer in the study area, we did not apply any refinement in the classification by moving some re- levés between clusters. We justify this approach owing to insufficient field experience needed to identify atypical or fragmentary stands. 
1.1.1

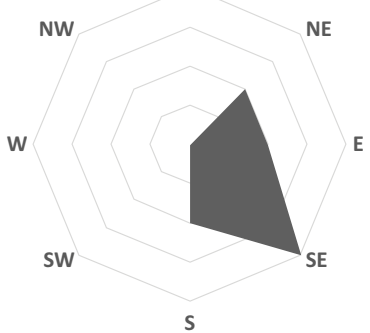

1.2.2

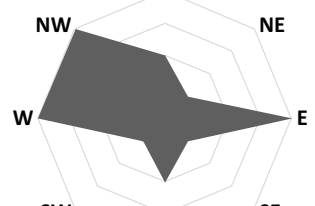

sW

SE

S

2.1.3
1.1.2

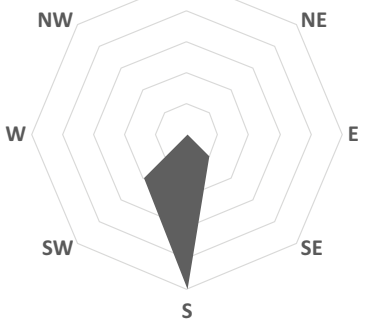

2.1.1

N

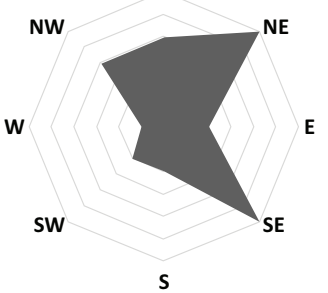

3.1.1
1.2.1

N

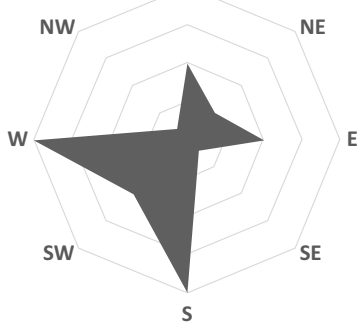

2.1.2

N

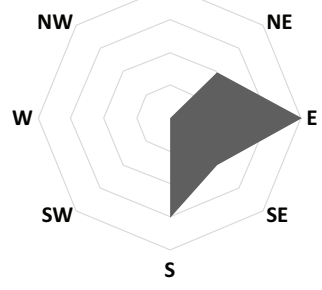

3.2.1

N

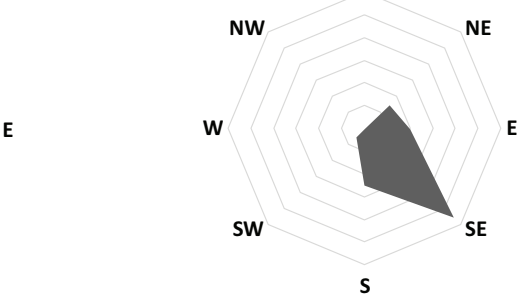

3.2.2

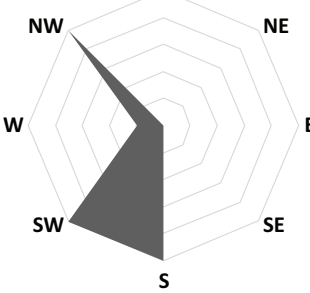

NE

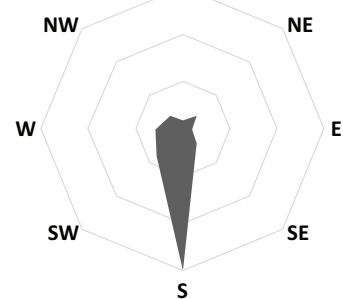

E

E

3.2.3

N

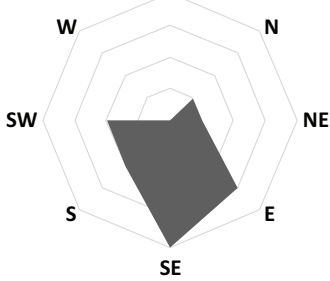

NE

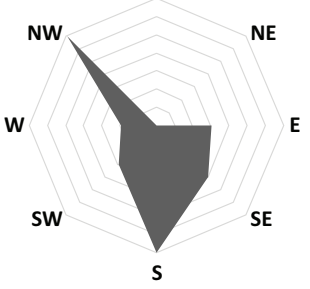

Fig. 5. The aspect preferences of the researched associations. Abbreviations of plant communities follow Fig. 2.

\section{Syntaxonomical synopsis}

Class: Ajanio-Cleistogenetea songoricae (Mirkin in Kashapov et al. 1987) Mirkin et al. 1988

1. Order: Ajanio-Cleistogenetalia songoricae (Mirkin in Kashapov et al. 1987) Mirkin et al. 1988

1.1. Alliance: Piptathero gracilis-Artemision brevifoliae Eberhardt 2004

1.1.1. Serratula procumbens-Stipa caucasica subsp. desertorum community

1.1.2. Astragalo chomutowii-Stipetum subsessiliflorae A. Nowak et al. 2018

1.2. Alliance: Ajanio-Cleistogenenion songoricae (Mirkin in Kashapov et al. 1987) Mirkin et al. 1988

1.2.1.Stipa krylovii-Stipa breviflora community

1.2.2. Stipetum bungeanae A. Nowak et al. 2018 
Class: Astragalo microcephali-Brometea tomentelli Quézel 1973

2. Order: Carici stenophylloidis-Stipetalia arabicae ord. prov.

2.1. Alliance: Poo bulbosae-Artemision persicae A. Nowak et al. 2016

2.1.1. Convolvuletum spiniferi A. Nowak et al. 2018

2.1.2. Elytrigia trichophora-Linum corymbulosum community

2.1.3. Stipo magnificae-Otostegietum olgae A. Nowak et al. 2018

Class: Cleistogenetea squarrosae Mirkin et al. ex Korotkov et al. 1991

3. Order: Stipetalia krylovii Kononov et al. 1985

3.1. Alliance: unknown

3.1.1. Littledaleo alaicae-Stipetum trichoidis A. Nowak et al. 2018

3.2. Alliance: Stipion krylovii Kononov et al. 1985

3.2.1. Astracantha pterocephala-Dracocephalum bipinnatum community

3.2.2. Helictotricho fedtschenkoi-Stipetum kirghisori A. Nowak et al. 2018

3.2.3. Astragalo lithophili-Stipetum zalesskii A. Nowak et al. 2018

\section{High-altitude arid steppes}

1.1.1. Serratula procumbens-Stipa caucasica subsp. desertorum community

Diagnostic species: Serratula procumbens, Stipa caucasica subsp. desertorum,

Constant species: Eremopyrum distans, Serratula procumbens, Stipa caucasica subsp. desertorum,

Dominant species: Stipa caucasica subsp. desertorum, $S$. arabica

Floristic and habitat characteristics: As the position of Stipa cancasica subsp. desertorum is still vague regarding the rank within the Stipa sect. Smirnovia, we decided to define this type of desert steppe as rankless. We recorded plots of the community only in eastern Pamir in Tajikistan and in the eastern part of the Alai Valley in Kyrgyzstan. They occupy the highest and driest sites in cold, high-altitude belts (Fig. 4). The community has sparse cover and patchy physiognomy and develops on vast, generally flat areas. The Serratula procumbens-Stipa caucasica subsp. desertorum community was found on fine rock debris or sometimes sandy substrate with a low cover of organic top soils (Fig. 4). There are several species within the sampled plots with the Central Asian distribution range: Acantholimon tianschanicum, Braya pamirica, Dianthus tianschanicus. The most frequent species in this community include Allium oreoprasum, Artemisia skorniakovii, Eremopyrum distans, Krascheninnikovia ceratoides and Stipa orientalis.

1.1.2. Astragalo chomutowii-Stipetum subsessiliflorae ass. nova hoc loco

Diagnostic species: Acantholimon bedini, Androsacae dasyphylla, Astragalus chomutowii, Ephedra regeliana, Euphrorbia tranzschelii, Stipa subsessiliflora

Constant species: Artemisia skorniakovii, Astragalus chomutowii, Ephedra regeliana

Dominant species: Ephedra regeliana, Stipa caucasica, $S$. orientalis, S. subsessiliflora
Floristic and habitat characteristics: The main diagnostic species, Stipa subsessiliflora, is a high mountain plant with a relatively wide range, however restricted only to the alpine and the nival belts (ca. 5,200 m a.s.l.) in the mountains of Central Asia (eFloras 2017). During the study, plots with Stipa subsessiliflora were found in several locations in the eastern part of the Alai Valley. When compared to other steppe plant communities occurring in Middle Asia, this association exhibits the highest elevational range in the arid areas of the Central Asian uplands (Figs 1, 4). Phytocoenoses were noted on flat lands with stony or sandy substrates (Figs 4,5 ). In addition to the diagnostic taxa, the most frequently contributing plants to this community were Artemisia skorniakovii, Eremopyrum distans, Krascheninnikovia ceratoides and Poa bulbosa.

Typus relevé: (relevé number in Supplement S1 - 29). 4 July 2015; Sary-tash: $39.06723^{\circ} \mathrm{N} ; 73.78315^{\circ} \mathrm{E} ; 3160 \mathrm{~m}$ a.s.l.; plot area $20 \mathrm{~m}^{2}$; species richness: 11 ; species composition: Stipa subsessiliflora 2, Androsace dasyphylla 1, Artemisia skorniakovii 1, Ephedra regeliana 1, Euphorbia tranzschelii 1, Allium jacquemontii +, Astragalus chomutowii +, Eremopyrum distans +, Festuca valesiaca +, Oxytropis bella + , Stipa cancasica + .

\subsubsection{Stipa krylovii-Stipa breviflora community}

Diagnostic species: Achnatherum splendens, Allium veschnjakovii, Agropyron cristatum, Artemisia hedini, Chenopodium album, Ch. aristatum, Cleistogenes squarrosa, Heteropappus canescens, Stipa breviflora, S. krylovii, Torularia korolkovii

Constant species: Achnatherum splendens, Heteropappus canescens, Stipa krylovii

Dominant species: Stipa breviflora, S. krylovii, S. macroglossa subsp. kazachstanica, S. sareptana, Neopallasia pectinata

Floristic and habitat characteristics: During the research, several plots of the community were recorded on the southern slopes and plains in the Issyk-Kul valleys. The 
plots with Stipa breviflora and S. krylovii occur on flat land or gentle slopes with a high amount of organic matter with scarce gravel debris or sand $\mathrm{n}$ the topsoil layer (Fig. 4). This community hosts some taxa generally considered as diagnostic for the Central Asian dry steppes, such as Chorispora sibirica, Stipa breviflora, S. glareosa, S. macroglossa subsp. kazachstanica, S. sareptana and Neopallasia pectinata.

\subsubsection{Stipetum bungeanae ass. nova hoc loco}

Diagnostic species: Artemisia kuschakeviczii, Peganum harmala, Plantago minuta, Salsola drobovii, S. orientalis, Stipa bungeana, S. glareosa, Trigonella arcuata

Constant species: Artemisia kuschakeviczii, Stipa glareosa Dominant species: Achnatherum splendens, Artemisia kuschakeviczii, Ceratocarpus utriculosus, Helianthemum songaricum, Stipa bungeana, S. glareosa, S. sareptana Floristic and habitat characteristics: The Stipetum bungeanae was found in the upper montane belt on gentle slopes. In this area, soil is almost deprived of organic matter and is covered by tiny rock debris and gravel. It is windswept and looks as a smooth, closely packed pavement typical for semi-desert conditions. Frequent taxa include Anabasis truncata, Astragalus muschketovii, Chorispora sibirica, Ephedra equisetina, Krascheninnikovia ceratoides and Nanophyton erinaceum.

Typus relevé: (relevé number in Supplement S1 - 60). 8 July 2015; Balykchy: $42.59924^{\circ} \mathrm{N} ; 76.87946^{\circ} \mathrm{E} ; 1626 \mathrm{~m}$ a.s.l.; plot area $20 \mathrm{~m}^{2}$; species richness: 12 ; species composition: Salsola drobovii (b) 1, Salsola orientalis (b) 1, Artemisia kuschakeviczii 3, Stipa bungeana 3, Alyssum desertorum 1, Astragalus muschketovii 1, Ephedra equisetina 1, Plantago minuta 1, Allium veschnjakovii + , Artemisia persica + , Carex pachystylis + , Trigonella arcuata + .

\section{Dry, thermophilous steppes of montane and subalpine belt in continental climate}

\subsubsection{Convolvuletum spiniferi ass. nova hoc loco}

Diagnostic species: Alyssum campestre, Artemisia persica, Bromus lanceolatus, Convolvulus spinifer, Eremurus sogdianus, Erysimum diffusum, Sanguisorba alpina, Scabiosa olivieri, Stipa drobovii var. iskanderkulica, Taeniatherum crinitum

Constant species: Alyssum campestre, Artemisia persica, Botriochloa ischaemum, Centaurea squarrosa, Convolvulus spinifer, Taeniatherum crinitum

Dominant species: Artemisia persica, Convolvulus spinifer

Floristic and habitat characteristics: The Convolvuletum spiniferi was found rarely in the valleys of the Fergana range (e.g. Kara-kol vicinity) and in the western Alai range (near Kara-bulak). It occurs in the montane and colline belt in warm and relatively dry sites (Fig. 4). The substrate is almost deprived of an organic soil layer and the ground is covered by stable rocky debris. In terms of the topsoil substrate conditions, these sites resemble scree habitats (Plate 1). In addition to the diagnostic taxa, the most abundant species were Cerasus verrucosa, Poa bulbosa and Stipa bohenackerana. The presence of Centaurea squarrosa and Ziziphora tenuior is due to the close spatial contact between the Convolvuletum spiniferi and the adjacent dry meadows, whereas the occurrence of $A r$ temisia rutifolia, Callipeltis cucullaris, Crambe kotschyana and Stipa caucasica reflects the similarity of this habitat to the scree environments.

Typus relevé: (relevé number in Supplement S2 - 13). 30 June 2015; Kara-kol: $41.64254^{\circ} \mathrm{N}$; $72.72220^{\circ} \mathrm{E}$; $1485 \mathrm{~m}$ a.s.l.; plot area $20 \mathrm{~m}^{2}$; species richness: 16 ; species composition: Convolvulus spinifer 3, Bothriochloa ischaemum 2, Perovskia abrotanoides 2, Acanthophyllum subglabrum 1, Alyssum campestre 1, Centaurea squarrosa 1, Eremurus sogdianus 1, Henrardia persica 1, Artemisia persica +, Astragalus sp. + , Bromus lanceolatus + , Diarthron vesiculosus + , Krascheninnikovia ceratoides + , Rochelia leiocarpa + , Scabiosa olivieri +, Taeniatherum crinitum + .

\subsubsection{Elytrigia trichophora-Linum corymbulosum com-} munity

Diagnostic species: Achillea biebersteinii, Alyssum dasycarpum, Anagallis arvensis, Botriochloa ischaemum, Bromus japonicus, B. oxyodon, Centaurea squarrosa, Centaurium pulchellum, Elaeosticta birtula, Elytrigia trichophora, Eremurus tianschanicus, Linum corymbulosum, Medicago sativa, Plantago lanceolata, Sideritis montana, Velezia rigida, Ziziphora interrupta

Constant species: Alyssum dasycarpum, Bothriochloa ischaemum, Centaurea squarrosa, Diarthron vesiculosus, Elytrigia trichophora, Linum corymbulosum

Dominant species: Botriochloa ischaemum, Stipa margellanica, Elytrigia trichophora, Dracocephalum diversifolia, Bunium persica, Artemisia tenuisecta

Floristic and habitat characteristics: At low altitudes we found several stands that reveal the transitional characters between steppes and dry meadows that are regularly mowed and occur inside the forest zone. In fact, the difference between these types of vegetation is vague and the colourful plots with considerable contribution of dicots could be finally included into dry steppes of the Poo bulbosae-Artemision persicae. The relation between these types of vegetation is still unclear, and the issue requires further study, particularly in the Fergana Basin and in southwestern Tajikistan, as well as comparative analysis with the dry steppes of southern Siberia and Kazakhstan. Species like Achillea biebersteinii, Centaurea squarrosa, Linum corymbulosum and Velezia rigida have their ecological amplitude in the warmest habitats with a high amount of spring or winter precipitation. The documented plots were found on substrates with a well-developed organic soil layer with a small amount of gravel debris (Figs. 4, 5). 
2.1.3. Stipo magnificae-Otostegietum olgae ass. nova hoc loco

Diagnostic species: Aegilops cylindrica, A. triuncialis, Arnebia coerulea, Artemisia kochiiformis, Bromus danthoniae, Carthamus lanatus, Elytrigia ferganensis, Eremodaucus lehmanniana, Glaucium squamigerum, Haplophyllum ferganensis, Otostegia olgae, Silene brabuica, Stipa arabica, S. bohenackerana, S. magnifica, Strigosella trichocarpa, Ziziphora tenuior

Constant species: Aegilops triuncialis, Artemisia kochiiformis, Centaurea squarrosa, Otostegia olgae, Stipa magnifica

Dominant species: Artemisia kochiiformis, Otostegia olgae, Stipa macroglossa

Floristic and habitat characteristics: Stands of this community occurred around the southern shores of the Toktogul Lake and in the colline belt of the central and western Alai Mts. (Fig. 4). They are clearly identifiable in the landscape because of the patchy physiognomy of the association, this latter being composed of cushions of the dwarf shrub Otostegia olgae distributed upon a sparse herb layer cover (Supplement S4). Due to erosion and denudation, the organic soil is scarce and the substrate is loamy, deep, often of a reddish colour. The contribution of species typical for xerothermophilous habitats is evidenced by the presence of Centaurea squarrosa, Consolida stocksiana, Convolvulus pseudocantabrica, Gammanthus ferganicus, Heliotropium olgae, Lepechiniella ferganensis and Polygonum mezianum.

Typus relevé: (relevé number in Supplement S2 - 53). 1 July 2015; Osh: $40.38977^{\circ} \mathrm{N} ; 72.74424^{\circ} \mathrm{E} ; 1340 \mathrm{~m}$ a.s.l.; plot area $20 \mathrm{~m}^{2}$; species richness: 27 ; species composition: Artemisia persica 2, Otostegia olgae 2, Centaurea squarrosa 1, Eremopyrum bonapartis 1, Stipa magnifica 1, Carthamus lanatus +, Bromus danthoniae 1, Eremodaucus lehmanniana 1, Glaucium squamigerum 1, Acanthophyllum albidum +, Astragalus junusovii + , A. ophiocarpus + , Arnebia coerulea + , Artemisia kochiiformis +, Bromus lanceolatus +, Convolvulus pseudocantabrica +, Cousinia submutica +, Elytrigia ferganensis +, Gammanthus ferganicus + , Haplophyllum acutifolium,$+ H$. ferganensis + , Koelpinia linearis + , Lactuca tatarica,$+ \mathrm{Li}$ num corymbulosum + , Silene brabuica + , Stipa arabica + , Strigosella trichocarpa + .

\section{Mountain steppes of semi-arid areas}

3.1.1. Littledaleo alaicae-Stipetum trichoidis ass. nova hoc loco

Diagnostic species: Artemisia sieversiana, Astragalus kokandensis, Festuca rupicola, Littledalea alaica, Galium tianschanicum, Stipa turkestanica subsp. trichoides Constant species: Carex turkestanica, Stipa turkestanica subsp. trichoides,
Dominant species: Ajania fastigiata, Artemisia skorniakovii, Elymus dasystachys, Stipa arabica, S. glareosa, S. krylovii, Stipa turkestanica subsp. trichoides

Floristic and habitat characteristics: The plots of the association were found in highly elevated parts in the alpine belt of the Alai (Fig. 4). The association inhabits mainly flat areas with the physiognomy of 'grassy' steppe (Supplement S4). Littledaleo alaicae-Stipetum trichoidis prefers sites with a well-developed organic soil layer and scarce gravel debris. The altitudinal range and the microclimatic characteristic of the association stands is emphasized by the occurrence of several species typical for cryophilous semi-deserts and screes, such as Acantholimon linczerskii, A. komarovii, Artemisia lehmanniana, Poa relaxa, Stipa glareosa.

Typus relevé: (relevé number in Supplement S3 - 13). 24 July 2016; Alay Valley: $39.65313^{\circ} \mathrm{N} ; 72.87758^{\circ} \mathrm{E} ; 2950 \mathrm{~m}$ a.s.l.; plot area $20 \mathrm{~m}^{2}$; species richness: 17 ; species composition: Eremopyrum distans 2, Stipa turkestanica subsp. trichoides 2, Acantholimon komarovii 1, Artemisia tenuisecta 1, Diarthron vesiculosus 1, Serratula procumbens 1 , Thymus diminutus 1, Allium oreoprasum +, A. tianschan$i$ cum + , Astragalus alexenkoi + , A. kokandensis,+ A. taldycensis + , Festuca rupicola + , Hedysarum krylovii + , Lappula stricta + , Littledalea alaica + , Senecio kraschennikovii + .

\subsubsection{Astracantha pterocephala-Dracocephalum bipinna-} tum community

Diagnostic species: Allium pallasii, Astracantha pterocephala, Dracocephalum bipinnatum, Elaeosticta ferganensis, Hedysarum pavlovii, Jurinea abolini, Melica secunda, Patrinia intermedia, Rosularia borissovae, Ziziphora clinopodioides

Constant species: Artemisia rutifolia, Dracocephalum bipinnatum, Ziziphora clinopodioides

Dominant species: Dracocephalum bipinnatum, Ephedra botschanzevii, Piptatherum songorica, Stipa caucasica, S. macroglossa subsp. kazachstanica

Floristic and habitat characteristics: This community occurs in the eastern Kyrgyzstan within the colline belt in the surroundings of the eastern side of the Issyk-Kul Lake. Among the presented plant communities, this one is the most scree-like, with a low cover of organic top soil and a considerable amount of gravel and rock debris on the ground (Fig. 4; Supplement 4). Several plots are dominated by feather grass species (e.g. Stipa macroglossa subsp. kazachstanica), whereas in other plots the succulent species exhibit high cover values (e.g. Rosularia borissovae). The habitat similarities with scree vegetation are revealed by a contribution of Artemisia rutifolia, Patrinia intermedia, Piptatherum songoricum, Silene brahuica and Stipa cancasica. However, the majority of plots presents the typical steppe physiognomy with the dominance of Stipa capillata, S. caucasica and S. macroglossa subsp. kazachstanica. 
3.2.2. Helictotricho fedtschenkoi-Stipetum kirghisori ass. nova hoc loco

Diagnostic species: Artemisia pamirica, Festuca valesiaca, Helictotrichon fedtschenkoi, Leontopodium ochroleucum, Stipa kirghisorum

Constant species: Carex turkestanica, Festuca valesiaca, Stipa kirghisorum

Dominant species: Artemisia skorniakovii, Festuca valesiaca, F. kirilowii, Medicago lupulina, Stipa cancasica, S. kirghisorum

Floristic and habitat characteristics: This association was found in the Suusamyr and Alai Valleys in central TianShan and the eastern Alai Mts. The phytocoenosis prefers habitats with a well-developed top soil layer and low content of gravel debris (Supplement S4). Although the group of diagnostic species seems to be well suited and stable, there are components of other types of vegetation within the community showing the ecological relations of this steppe association. Among the most frequent are scree species, such as Artemisia rutifolia, Poa relaxa or Stipa caucasica and alpine plants like Astragalus nivalis, Dracocephalum komarovii, Potentilla hololeuca and $P$. moorkroftii.

Typus relevé: (relevé number in Supplement S3 - 59). 3 June 2015; Alay Valley: N 39.68755; E 73.23192; 3110 m a.s.l.; plot area $20 \mathrm{~m}^{2}$; species richness: 12 ; species composition: Stipa kirghisorum 3, Artemisia pamirica 1, Carex turkestanica 1, Festuca valesiaca 1, Helictotrichon fedtschenkoi 1, Androsace dasyphylla +, Eremopyrum distans +, Erigeron trimorphopsis +, Galium saurense +, Leontopodium ochroleucum +, Myosotis micrantha +, Oxytropis guntensis + .

3.2.3. Astragalo lithophili-Stipetum zalesskii ass. nova hoc loco

Diagnostic species: Artemisia dracunculus, A. maracandica, Astragalus lithophilus, A. mucidus, Eremurus fuscus, Erysimum diffusum, Euphrasia regelii, Festuca valesiaca, Helichrysum maracandicum, Pedicularis olgae, Poa pratensis, Potentilla canescens, Pseudosedum condensatum, Stipa capillata, S. zalesskii, Thymus proximus

Constant species: Artemisia dracunculus, Erysimum diffusum, Euphrasia regelii, Festuca valesiaca, Stipa capillata Dominant species: Artemisia maracandica, Carex pachystylis, Eremurus fuscus, Festuca valesiaca, Jurinea lanipes, Stipa capillata, S. cancasica, S. kirghisorum, Stipa turkestanica subsp. trichoides, $S$. zalesskii

Floristic and habitat characteristics: Plant communities dominated by Stipa zalesskii were found in several locations in central Tian-Shan, mainly in the hilly lands in the Suusamyr Valley. They occur at alpine altitudes on flat or slightly sloping sites (Fig. 4; Supplement S4). The phytocoenoses grow on well-developed soils with an inconsiderable amount of gravel debris in the upper layer. This is the densest and most forage-efficient steppe type in the research area. The core set of plants is typical for steppe vegetation. Only in a few plots, noticeably on sloping hills or in a higher elevation, was the increased contribution of scree species found (e.g. Artemisia rutifolia, Poa relaxa, Stipa cancasica).

Typus relevé: (relevé number in Supplement S3 - 79). 29

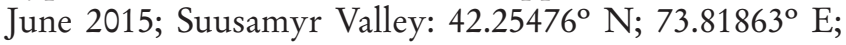
$2258 \mathrm{~m}$ a.s.l.; plot area $20 \mathrm{~m}^{2}$; species richness: 22; species composition: Artemisia maracandica 3, Stipa zalesskii 3, Astragalus lithophilus 1, Eremostachys speciosa 1, Carex pachystylis 1, Eremurus fuscus 1, Erysimum diffusum 1, Euphorbia ferganensis 1, Festuca valesiaca 1, Galium pamiroalaicum 1, Koeleria cristata 1, Pedicularis olgae 1, Thymus proximus 1, Ziziphora bungeana 1, Artemisia rutifolia + , Helichrysum maracandicum + , Heteropappus canescens + , Polygonum alpinum + , Rochelia bungei + , Scabiosa alpestris + , Scorzonera pusilla + , Stipa capillata + .

\section{Discussion}

\section{Syntaxonomical remarks}

\section{High-altitude arid steppes}

As we highlighted in our first study devoted to feather grass steppes in the western Pamir Alai (Nowak et al. 2016), Middle Asia is strongly heterogeneous in terms of geomorphology, climate and soil. In effect, within one climatic zone, e.g. cold mountainous semi-arid areas, one can find different vegetation composed of a large set of species. Most of the distinguished vegetation types are well defined by numerous diagnostic plants. The number of diagnostic taxa varied between five and 17, and only in one case, the community of Serratula procumbens-Stipa cancasica subsp. desertorum, it was lower. In this phytocoenosis the only two diagnostic species highlight the extremely dry and harsh conditions with species poor vegetation in easterm Pamir. The TWINSPAN results display the climatic division of the research area. The first group of plant communities are strictly related to the high-altitude deserts of eastern Pamir and the eastern part of the Alai Valley. Despite the fairly distinct elevation (ca. $2000 \mathrm{~m}$ lower), in our opinion the steppe communities of the western part of the Issyk-Kul basin should be also included in this group. This area is located in the subalpine belt (ca. 1650-1850 m a.s.l.) in the northernmost part of the study area and is therefore strongly influenced by a rainshadow effect and continental climate due to its downwind location. For this severely arid area, four species poor plant communities were distinguished: the Serratula procumbens-Stipa cancasica subsp. desertorum community, Astragalo chomutowii-Stipetum subsessiliflorae, Stipetum bungeanae and Stipa krylovii-Stipa breviflora community. The species composition of these phytoceonoses is clearly distinct from other associations occurring in the research area. In particular, the relatively 
low cover of herbaceous layer and the occurrence of species typical for the Central Asian highlands such as Ermannia crassifolia, Eremopyrum distans, Oxytropis bella, Acantholimon tianschanicum, Halogeton glomeratus and Euphorbia tranzschelii articulate their unique character within the study area. The most similar to the abovementioned vegetation are the plant communities from the Hindu Kush and the Karakorum Mts. They reflect similar physiognomy and average total vegetation cover (approx. 5-45\%) and species richness (approx. 3-15) per plot (Eberhardt 2004; Peer et al. 2007). These plant communities were included in the alliance Piptathero gracilisArtemision brevifoliae as a mountain dwarf-scrub steppe of high western Asia. It was considered as a semi-deserted cold steppe with sparse vegetation cover at the high altitudes of Central Asia. Comparing the earlier studies (e.g. Walter \& Breckle 1994), apparently the vegetation is similar to that distributed far to the north, including the central Tian-Shan and the Pamirs.

Despite the close distance between Karakorum and eastern Pamir, the floristic dissimilarities and the differences in ecological amplitude of particular species could be important. It should be considered that the latitudinal and longitudinal gradients in Middle Asia seriously change the environmental conditions due to extremely diverse orography, humidity and temperature. In our opinion, the desert steppes of the Central Asian highlands are probably a type of semi-desert rather than steppes. They are treeless areas, however, given the very low precipitation (often less than $100 \mathrm{~mm}$ per year), this vegetation has the thorn-cushion physiognomy and the contribution of many species with adaptations to desert climates (thorns, spines, dominating life forms with many therophytes or geophytes that easily survive in extreme temperatures as seeds or bulbs/rhizomes). In addition, the total cover of herbaceous layer is, in many cases, particularly in Karakorum, but also in eastern Pamir, below the threshold value of $25 \%$ proposed for defining steppe (Wesche et al. 2016). This is reflected in the nomenclature of Russian botanists that gave the name pustosha (e.g. Stanyukovich 1982) for the kind of arid vegetation that is related rather to deserts than steppes. Despite that the comprehensive syntaxonomical system for cold deserts (or cryophilous steppes) for Central and Middle Asia is hardly achievable due to their exceptional richness and diversity, we believe that we are getting closer to a comprehensive hierarchical system.

Our dataset for the cold semi-deserts of the alpine belt of Central Asia is somehow heterogenous in terms of species composition, reflecting the different altitudinal range of the distinguished communities. Two communities (Astragalo chomutowii-Stipetum subsessiliflorae and Serratula procumbens-Stipa caucasica subsp. desertorum) occur in the highest elevation of the eastern Pamirian Plateau and in the eastern part of the Alai Valley, the next two (Stipa krylovii-Stipa breviflora community and Sti- petum bungeanae) in the much lower central Tian-Shan. In our opinion, according to TWINSPAN classification, despite some floristic dissimilarities, the latter two should also be included into Ajanio-Cleistogenenion songoricae that covers arid steppes of the montane belt in the northern part of Central Asia. This type of steppe was first distinguished by Yunatov $(1946,1974)$ and described as sparse, stony steppe dominated by feather-grasses of Stipa sectio Smirnovia (S. glareosa, S. gobica, S. cancasica), with a considerable share (up to $30 \%$ ) of dwarf shrubs, a lower contribution of graminoid perennials and a higher contribution of annuals in comparison to grassdominated steppes. The herb stands are relatively short (ca. 2-6 cm), with a low total cover of $12-16 \%$ and low species richness, with ca. 9-12 species per $100 \mathrm{~m}^{2}$ (Gadghiev et al. 2002). Although most of the taxa of the two areas (Mongolia in Central Asia and our own study area) differ, there are some floristic similarities at the species or genus taxonomical level: Ajania spp., Anabasis spp., Artemisia macrocephala, Krascheninnikovia ceratoides, Nanophyton spp., Neopalassia pectinata (= Artemisia pectinata), Salsola spp., Stipa breviflora and $S$. glareosa. However, the syntaxonomical position of the stands with Stipa breviflora and S. krylovii in Central Asia still remains vague to some extent. The community of Stipa breviflora was recently presented by Zheng et al. (2013) as developed on compact, stony substrate similar to desert pavements. Similar to other studies (e.g. Gadghiev et al. 2002; Ermakov 2012), it was characterised as sparse, short stands, poor in species. The physiognomy and species composition of this phytocoenosis show in the study area the transitional character between the cold deserts and deserted steppes included in Stipetalia krylovii.

\section{The mountain steppes of semi-arid areas}

The typical Central Asian steppes are represented in the study area by four vegetation types. Three of them are defined as associations (Littledaleo alaicae-Stipetum trichoidis, Helictotricho fedtschenkoi-Stipetum kirghisori, Astragalo lithophili-Stipetum zalesskii) and one is rankless-Astracantha pterocephala-Dracocephalum bipinnatum community. All these communities have been classified here into the order Stipetalia krylovii. These steppes were frequently reported from southern and eastern Siberia and Mongolia (Makunina 2006; Ermakov et al. 2009; Korolyuk \& Makunina 2009; Ermakov 2012). They have a grassland physiognomy and occupy the vast lowlands and mountains of temperate Asia. Stands of this vegetation are mainly composed of species typical for the Central Asian geobotanical subregion. If we compare the species composition of our steppes with those known from Mongolia or the southern Siberia, we can identify several diagnostic taxa in common, e.g. Agropyron cris- 
tatum or Stipa krylovii (see Korolyuk \& Makunina 2009; Ermakov 2012; Mamahatova 2013). Additionally, both areas share a number of other frequent species: Bothriochloa ischaemum, Centaurea squarrosa, Festuca valesiaca, Poa bulbosa, P. relaxa, Stipa capillata, S. cancasica, $S$ kirghisorum and $S$. sareptana. Also, the plot structure, the overall cover of herbaceous layer (ca. $50-80 \%$ ), the stand height $(\mathrm{ca} .50 \mathrm{~cm})$ and the species richness in plot (ca. 25-35) are similar in both Central and Middle Asia (Cheng et al. 2008 Ermakov 2012; Rachkovskaya \& Bragina 2012).

Dry, thermophilous steppes of montane and subalpine belt in continental climate

The last group, namely the xerothermophilous communities found in colline and montane belts, generally in the Fergana basin or foothills of the southern Fergana Range and northern parts of Alai range, should be linked to steppes that develop in warm, Irano-Turanian bioclimate (Nowak et al. 2016). Our opinion is based mainly on habitat comparisons and the physiognomy of vegetation with frequent and sometimes abundant contribution of dwarf shrubs and thorny cushion plants (e.g. Convolvulus spinifer). There are also compositional similarities, although as a result of the high endemism in Middle Asia (Nowak et al. 2011) and extremely diverse environment, the species shared in both regions are not so numerous. However, at generic level, one can easily find a close relation between the study area and other Irano-Turanian regions because of the structural resemblance of common species from the genera Acantholimon, Alyssum, Cousinia, Echinops, Nepeta, Pblomis, Salvia and Silene (Nowak et al. 2016; Kürschner \& Parolly 2012). For this type of steppe formations of warm and continental climates, the Carici stenophylloidis-Stipetalia arabicae was established (Nowak et al. 2016). It is probably related to the Astragalo microcephali-Brometalia tomentelli as it has species in common with Middle Asia. Species as Bothriochloa ischaemum, Bromus tectorum, Festuca valesiaca, Koeleria cristata, Poa bulbosa and Sideritis montana serve as examples (Quézel 1973; Parolly 2004; Hamzaoğlu et al. 2004; Saglam 2014). There is also some similarity in composition and physiognomy of Middle Asian steppes with the central Irano-Turanian areas. In the Alborz Mts. of Iran, steppe associations were reported with similar species richness and community structure. Plots consist of ca. 22-40 species in montane and subalpine warm zone and 5-15 species in steppes of high altitude belt or grasslands on saline soils. The thorny dwarf shrubs often dominate here in result of long Persian pastoral tradition (Akhani et al. 2013).

There are two communities identified in the study area as thermophilous, with dwarf-shrub or thorn-spiny physiognomy-Convolvuletum spiniferi and Stipo mag-
nificae-Otostegietum olgae. As in other vegetation types in the Western Asiatic Region of the Irano-Turanian Province, these two associations exhibit a high endemism rate in the species composition (up to $50 \%$ of the species number in a plot). This is why the floristic distinctiveness and the cluster dissimilarities are remarkable, despite the physiognomic attributes of the vegetation being fairly close. It is interesting to note that this specific physiognomy (thorny cushions, dwarf-shrubs), the relatively low herb layer cover, sometimes scree character of the substrate and other features related to the life form spectrum of species, makes these communities similar to those in the cold semi-deserts of the Hindu Kush, central Karakorum and eastern Pamir highlands. This can be a convincing argument when drawing the biogeographical boundary between the Western Asiatic (the Middle Asia) and central Asiatic subregion within the Irano-Turanian Province. The close relation between the dwarf-shrub steppes of central Karakorum and the Hindu Kush to the relevant communities in eastern Turkey and Iran was already noted by other geobotanists (Freitag 1971; Walter \& Box 1983; Kürschner 1986; Peer et al. 2007). They highlighted that the thorn-cushion rich dwarf shrublands of the cold deserts in the highlands represent an extreme outpost of the Irano-Turanian subalpine thorn-cushion belt, which is then absent further east (eastern Karakorum, Ladakh, Himalayas).

\section{Environmental variables determining the floristic composition of communities}

As was found for the steppes of western Pamir Alai (Nowak et al. 2016), the main environmental predictor of the species composition and distributional pattern of steppe vegetation in southwestern Tian-Shan and eastern Pamir is altitude. However, when comparing the results of the correspondence analysis it is clear that altitude is not responsible as the sole factor for the division into three main clusters. Longitude and organic soil content also have a strong influence on the data sets and make the main outline of the scattered plot (Fig. 6). The soil fertility and climatic conditions that are strongly influenced by the elevation are commonly accepted as crucial environmental variables that impact on steppe vegetation (Peer et al. 2007; Miehe et al. 2011). The three associations of Littledaleo alaicae-Stipetum trichoidis, Helictotricho fedtschenkoi-Stipetum kirghisori and Astragalo lithophili-Stipetum zalesskii, all prefer flat lands with a well-developed organic topsoil layer. The majority of the sampled plots were located in the western part of the research area (Fig. 6). The other group of communities that was found in the surroundings of the Issyk-Kul basin in central Tian-Shan and the easternmost parts of the Pamir Alai reveal opposite attributes in terms of soil organic content. They were found on bare lands with compacted, 


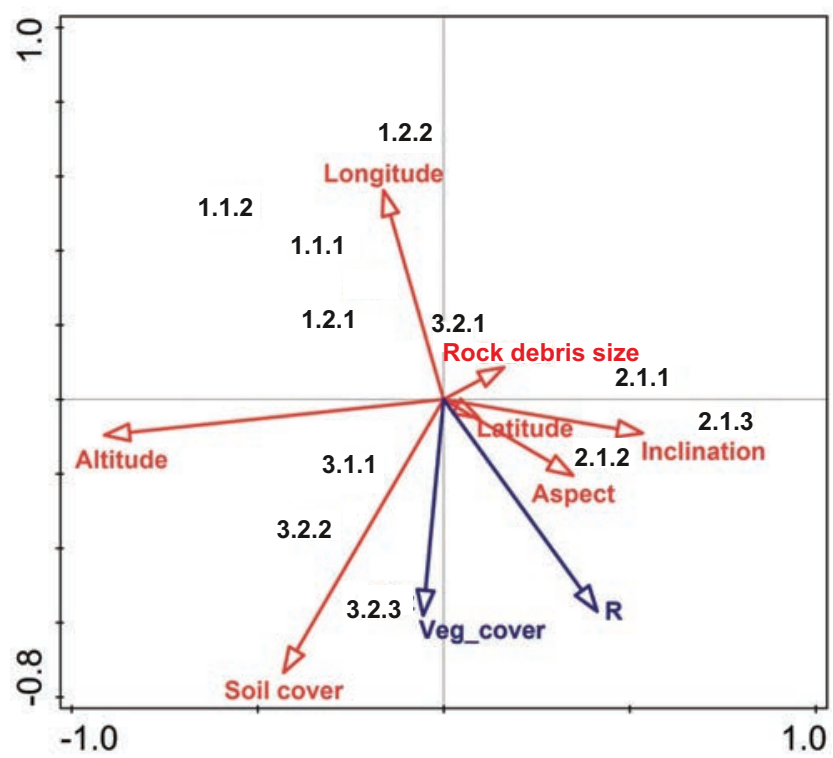

Fig. 6. CCA ordination for all relevés of steppe communities in the eastern Pamir and southwestern Tian-Shan $(N=274)$. Abbreviations of plant communities (black letters) follow Fig. 4. Veg_cover - cover of vegetation in a plot. Constrained variables are marked with red arrows. Supplementary variables are passively projected on the graph and depicted with blue arrows. The 7-degree Braun-Blanquet scale was transformed to a percentage cover scale (see Fig. 3). Total explained variation is 32.78 , explanatory variables account for $9.0 \%$. Permutation test results of all axes: pseudo- $F=3.8$, $p=0.002$. Eigenvalues: 0.68 (Axis 1), 0.66 (Axis 2).

gravelly pavements in semi-arid subalpine or alpine belts. It is also reflected by the 'gravel' variable in CCA. This group of plant communities could be also described as a group of the scarcest herbaceous layer and the lowest species richness. The longitudinal gradient seems to be a good predictor of species composition in the research area as well as the whole of Central Asia. Many other works claim the importance of longitudinal position in geobotanical analysis (Walter \& Box 1983; Peer et al. 2007). They show that moving from west to east, the aridity related to continentality, the decrease of precipitation amount and the increase in altitude are all key factors in determining the vegetation structure and composition.

A minor role, however an important one for the distinction of the Poo bulbosae-Artemision persicae communities, is played by slope inclination. This environmental predictor is important in distinguishing the Stipo magnificae-Otostegietum olgae and Convolvuletum spiniferi and, to a lesser extent, also the community of Elytrigia trichophora and Linum corymbulosum.

Grazing is another important factor that we did not study but that could shape species composition (Nüsser 1998; Peer 2000; Peer et al. 2001). In Middle and Central Asia, traditional livestock-keeping is still the main in- come source for the local people. However, the sophisticated pattern of herd movement and the low rate of repeatability of the grazing pattern in the mountainous areas, together with the changing congregation sites and herders' camps, does not allow for proxies that will be satisfactory in predicting real grazing intensity.

\section{Conclusions}

The paper is complementary to the study of steppe vegetation in the southern part of Middle Asia, with the focus on Tajikistan and Kyrgyzstan (Nowak et al. 2016). The study confirms the considerable diversity of steppe communities in the area and their transitional biogeographical position between the Western Asiatic subregion and Central Asiatic subregion within the IranoTuranian province. While the environmental conditions of both subregions overlap to some extent and interfuse in the borderland zone (e.g. in the Fergana Valley, western Turkestan Mts. and eastern Surhob Valley), the study clearly distinguishes the cold desert and arid steppes of Central Asia from the dry, thermophilous steppes of Middle Asia. In this 'knot' area of many mountain ranges with sophisticated bioclimatic isoline entanglement, further sampling is needed to reach a comprehensive classification of these steppes. Moreover, additional phytosociological studies should also be undertaken in neighbouring Afghanistan, western China and Uzbekistan. The classification studies of grasslands, and particularly of steppe vegetation, still needs to be intensified so as to be comparable to the outcomes of phytosociological research in the western part of the palearactic realm (Janišova et al. 2016). In particular, the relation of highaltitude arid steppes and cryophilous mountain semi-deserts needs to be thoroughly investigated.

Despite still insufficient research in the whole region, in our opinion, we are getting closer to establishing a consistent and comprehensive hierarchical syntaxonomical system for the steppe vegetation of Middle Asia. Further studies on Artemisia-dominated steppes and semideserts of colline and high alpine belts should support the final classification of the steppe biome in Middle and Central Asia. Beside the intrinsic scientific value of classification, the description of syntaxa can also assure the background for long-term monitoring and provide data for analysing vegetation changes in the future. It can also serve as useful tool for conservation and evaluation of the vegetation units against the endangerement criteria. Better understanding of the vegetation diversity and its changes is particularly important in vulnerable and valuable areas (Giam et al. 2010). In severely understudied regions it is higly recommended to establish a relevant and consistent classification as to allow more comprehensive comparisons at over-regional scales at different levels. Moreover, strengthening the botany and ecology 
programmes both in the administration and the educational system could help with establishing and implementing a finer vegetation classification and effective conservation of grassland diversity in this region.

\section{Author contributions}

M.N., Ar.N., and Ag.N. planned the research, Ar.N., M.N. and Ag.N. conducted the field sampling and identified the plant species, Ar.N and S.N. performed the statistical analyses, while all the authors participated in the writing of the manuscript. The research was partially founded by National Science Center, Poland, grant no 2017/25/B/NZ8/00572.

\section{Acknowledgements}

We are grateful to Firuza Illarionova from the Nature Protection Team, Dushanbe, for her assistance and help in organising the expeditions. Special thanks to Georgy Lazkov for his help in identification of the selected specimens collected during the studies. The project was supported by the National Science Centre, Poland, no. DEC-2013/09/B/ NZ8/03287.

\section{References}

Agakhanjanz, O.E. \& Breckle, S.-W. 2003. Vegetation of the Pamirs - classification, cartography, altitudinal belts. Bielefelder Ökologische Beiträge 18: 17-19.

Akhani, H., Mahdavi, P., Noroozi, J. \& Zarrinpour, V. 2013. Vegetation patterns of the Irano-Turanian steppe along a $3,000 \mathrm{~m}$ altitudinal gradient in the Alborz Mountains of Northern Iran. Folia Geobotanica 48: 229-255.

Baettig, R.B., Wild, M.M. \& Imboden, D.M. 2007. A climate change index: where climate change may be most prominent in the 21st century. Geophysical Research Letters 34: 457469.

Borchardt, P., Schickhoff, U., Scheitweiler, S. \& Kulikov, M. 2011. Mountain pastures and grasslands in the SW Tien Shan, Kyrgyzstan - floristic patterns, environmental gradients, phytogeography, and grazing impact. Journal of Mountain Science 8: 363-373.

Bragina, T.M., Wagner, V., Nowak, A. \& Vanselow, K.A. 2018. Grasslands of Kazakhstan and Middle Asia: the ecology, conservation and use of a vast and globally important area. In: Squires, V.R., Dengler, J., Feng, H. \& Hua, L. (eds.). Grasslands of the world: diversity, management and conservation. CRC Press, Boca Raton, US.

Braun-Blanquet, J. 1964. Pflanzensoziologie. Grundzüge der Vegetationskunde. Springer, Wien, AT.

Cherepanov, S.K. 1995. Plantae Vasculares URSS [Vascular plants of the Soviet Union]. Nauka, Leningrad, RU. [in Russian]

Cheng, Y., Tsendeekhuu, T., Narantuya, N. \& Nakamura, T. 2008. Phytosociological study of steppe vegetation in Mongolia. Grassland Science 54: 107-116.

Chytrý, M. \& Tichý, L. 2003. Diagnostic, constant and dominant species of vegetation classes and alliances of the Czech Republic: a statistical revision. Folia Facultatis Scientiarum
Naturalium Universitatis Masarykianae Brunensis 108: 1-231.

Dengler, J., Berg, C. \& Jansen, F. 2005. New ideas for modern phytosociological monographs. Annali di Botanica N.S. 5: 193-205.

Dengler, J., Chytry', M. \& Ewald, J. 2008. Phytosociology. In: Jørgensen, S.E. \& Fath, B.D. (eds.) Encyclopedia of ecology, pp. 2767-2779. Elsevier, Oxford, UK.

Dengler, J., Janišová, M., Török, P. \& Wellstein, C. 2014. Biodiversity of Palaearctic grasslands: a synthesis. Agriculture, Ecosystems and Environment 182: 1-14.

Djamali, M., Brewer, S., Breckle, S.W. \& Jackson, S.T. 2012. Climatic determinism in phytogeographic regionalization: A test from the Irano-Turanian region, SW and Central Asia. Flora 207: 237-249.

Eberhardt, E. 2004. Plant life of the Karakorum. The vegetation of the upper Hunza catchment (Northern Areas, Pakistan). Diversity, syntaxonomy, distribution. Dissertationes Botanicae 387: 1-223.

eFloras. 2017. Flora of China. Missouri Botanical Garden, St. Louis, MO. URL: http://www.efloras.org [accessed 20 July 2017].

Ermakov, N.B. 2012. Vysshie sintaksony nastajaschich opustinnenych stepey juzhnoy Sibirii i Mongolii. [Higher syntaxa of genuine deserted steppes of southern Siberia and Mongolia]. Vestnik NGU 10: 5-15. [in Russian]

Ermakov, N.B., Polyakova, M.A. \& Smorgov, A.E. 2009. Associacii petrofitnyh stepnyh soobschestv iz Altai-Sayanskoy gornoy oblasti. 1. Soobschestva Selaginella sanguinolenta Zapadnogo Sayana i Tuvy. [Steppe communities of petrophytic habitats in Altai-Sayan mountainous region]. Vestnik NGU 7: 35-42. [in Russian]

Fay, M. \& Patel, H. 2008. A simple index of vulnerability to climate change. Background paper prepared for World Bank report. Washington, DC, US.

Freitag, H. 1971. Die natürliche Vegetation Afghanistans. Beiträge zur Flora und Vegetation Afghanistans I. Vegetatio 22: 285-344.

Gadghiev, I.M., Korolyuk, A.Y., Tytlyanova, A.A., Andievsky, V.S., Bayartogtokh, B., Grishina, L.G., Kosykh, N.P., Kyrgys, C.O., (...) \& Smelyansky, I.E. 2002. Stepi Centralnoi Azii. [Steppes of Central Asia]. SB RAS Publisher, Novosibirsk, RU. [in Russian]

Giam, X., Bradshaw, C.J.A., Tan, H.T.W. \& Sodhi, N.S. 2010. Future habitat loss and the conservation of plant biodiversity. Biological Conservation 143: 1594-1602.

Hamzaoğlu, E., Aydoğdu, M., Kurt, L. \& Cansaran, A. 2004. New syntaxa from the west part of Central Anatolia. Pakistan Journal of Botany 36: 235-246.

Hennekens, S.M. \& Schaminée, J.H.J. 2001. TURBOVEG, a comprehensive data base management system for vegetation data. Journal of Vegetation Science 12: 589-591.

Hill, M.O. 1979. TWINSPAN - A FORTRAN program for arranging multivariate data in an ordered two-way table by classification of the individuals and attributes. Ecology and Systematics, Cornell University, Ithaca, New York, US.

Janišova, M., Dengler, J. \& Willner, W. 2016. Classification of Palearctic grasslands. Phytocoenologia 46: 233-239.

Korolyuk, A.Y. \& Makunina, N.I. 2009. True steppes of the Altai-Sayan mountain area (Order Stipetalia krylovii Kononov, Gogoleva et Mironova 1985). Rastitelnyi Mir Asiatskoi Rasii 2: 45-53. [in Russian]

Korovin, E.P. 1962. Rastitel'nost' Sredney Azii i Yuzhnogo Kazakhstana. [Vegetation of Middle Asia and southern $\mathrm{Ka}$ - 
zakhstan]. Vol. 2, 2nd ed. Izdatelstvo Akademii Nauk Uzbekskoy SSR, Taschkent, UZ. [in Russian]

Kovalevskaya, S.S. 1968. Opredelitel rastenii Srednej Azii. [Determination key to the flora of Middle Asia]. Vol. I. Akademia Nauk USSR, Izdatelstvo "FAN" Uzbekskoi SSR, Tashkent, UZ. [in Russian]

Kürschner, H. 1986. The subalpine thorn-cushion formations (Tragacanthic vegetation) of western South-West Asia. Ecology characteristics, structure and zonation. Proceedings of the Royal Society of Edinburgh 89: 169-179.

Kürschner, H., \& Parolly, G. 2012. The Central Anatolian steppe. In: Werger, M.J.A. \& van Staalduinen, M.A. (eds.) Eurasian steppes. Ecological problems and liveliboods in a changing world, pp. 149-172. Springer, Dordrecht, NL.

Latipova, W.A. 1968. Kolichestvo osadkov [Precipitation]. In: Narzikulov, I.K. \& Stanyukovich, K.W. (eds) Atlas Tajikskoi SSR, pp. 68-69. Akademia Nauk Tajikskoi SSr, DushanbeMoskva, TJ. [in Russian]

Lavrenko, E.M., Karamysheva, Z.V. \& Nikulina, R.I. 1991. Steppes of Eurasia. Leningrad, Science, RU.

Lipskyi, V.I. 1903. Flora Sredney Azii t.e. Russkago Turkestana $i$ khanstv Bukbary $i$ Khivy. [The flora of Middle Asia Russian Turkestan and chanats of Bukhara and Khiva]. Vol. 2. Istoriya botanicheskogo issledovaniya Sredney Azii. St. Petersburg, RU. [in Russian]

Makunina, N.I. 2006. Stepi Minusinskih Kotlovin. [Steppes of Minusin Basins]. Turczaninovia 9: 112-144. [in Russian]

Mamahatova, W.A. 2013. Klassifikacya vysokogornoy rastitelnostii zapadnoy i centraloy chastii hrebta Chikaeva (JugoVostochnyi Altai). [Alpine vegetation classification of the western and central section of Chikaev Range]. Izvestya Samarskogo Centra Rassijskoy Akademii Nauk 15: 383-387. [in Russian]

Michl, T., Dengler, J. \& Huck, S. 2010. Montane-subalpine tallherb vegetation (Mulgedio-Aconitetea) in central Europe: large-scale synthesis and comparison with northern Europe. Phytocoenologia 40: 117-154.

Miehe, G., Bach, K., Miehe, S., Kluge, J., Yongping, Y., Duo, L., Co, S. \& Wesche, K. 2011. Alpine steppe plant communities of the Tibetan highlands. Applied Vegetation Science 14: 547560.

Mittermeier, R.A., Gil, P.R., Hoffman, M., Pilgrim, J., Brooks, T., Goettsch-Mittermeier, C., Lamoreux, J. \& da Fonseca, G.A.B. 2006. Hotspots revisited: Earth's biologically richest and most threatened terrestrial ecoregions. Conservation International, UK.

Narzikulov, I.K. \& Stanyukovich, K.W. 1968. Atlas Tajikskoi SSR. [Atlas of the Tajik SSR]. Akademia Nauk Tajikskoi SSR, Dushanbe, TJ. [in Russian]

Nowak, A., Nowak, S. \& Nobis, M. 2011. Distribution patterns, ecological characteristic and conservation status of endemic plants of Tadzhikistan - A global hotspot of diversity. Journal for Nature Conservation 19: 296-305.

Nowak, A., Nowak, S., Nobis, A. \& Nobis, M. 2016. Vegetation of feather grass steppes in the western Pamir Alai Mountains (Tajikistan, Middle Asia). Pbytocoenologia 46: 295-315.

Nowak, A., Nobis, M., Nowak, S., Nobis, A., Swacha, G. \& Kącki, Z. 2017. Vegetation of Middle Asia - the project state of art after ten years of survey and its future perspectives. Phytocoenologia 47: 395-400.

Nüsser, M. 1998. Nanga Parbat (NW-Himalaya): Naturräumliche Ressourcenausstattung und humanökologische Gefügemuster der Landnutzung. Bonner Geographische Abhandlungen 97: 1-226.
Ovchinnikov, PN. 1971. Vidovoy sostav rastitelnogo pokrova ushchelya reki Varzob. 1. Vyshe rastenya. [The flora of the Varzob River Valley]. In: Ovchinnikov, P.N. (ed.), Flora $i$ rastitelnost ushchelya reki Varzob. Leningrad: Izdatelstvo Nauka, RU. [in Russian]

Parolly, G. 2004. The high mountain vegetation of Turkey - a state of the art report, including a first annotated conspectus of the major syntaxa. Turkish Journal of Botany 28: 39-63.

Peer, T. 2000. The highland steppes of the Hindu Kush Range as indicators of centuries old pasture farming. Marburger Geographische Schriften 135: 312-325.

Peer, T., Millinger, A., Gruber J. P. \& Hussain, F. 2001. Vegetation and altitudinal zonation in relation to the impact of grazing in the steppe lands of the Hindu Kush Range (NPakistan). Phytocoenologia 31: 477-498.

Peer, T., Gruber, J.P., Millinger, A. \& Hussain, F. 2007. Phytosociology, structure and diversity of the steppe vegetation in the mountains of Northern Pakistan. Phytocoenologia 37: $1-65$.

Quézel, P. 1973. Contributions à l'étude phytosociologiques du massif du Taurus. Phytocoenologia 1: 131-222.

Rachkovskaya, E.I. \& Bragina, T.M. 2012. Steppes of Kazakhstan: diversity and present state. In: Werger, M.J.A. \& van Staalduinen, M.A. (eds.) Eurasian steppes. Ecological problems and liveliboods in a changing world, pp. 103-148. Springer, Dordrecht, NL.

Rachkovskaya, E.I., Volkova, E.A. \& Khramtsov, V.N. 2003. Botanical geography of Kazakbstan and Middle Asia (desert region). Komarov Botanical Institute, St Petersburg, RU.

Roleček, J., Tichý, L., Zelený, D. \& Chytrý, M. 2009. Modified TWINSPAN classification in which the hierarchy respects cluster heterogeneity. Journal of Vegetation Science 20: 596602.

Safarov, N. 2003. National strategy and action plan on conservation and sustainable use of biodiversity. Governmental Working Group of the Republic of Tajikistan. Dushanbe, TJ.

Saglam, C. 2014. Phytosociological features of Cicek Mountain and environs (Isparta, Turkey). Ekoloji 23: 19-37.

Smelansky, I.E. \& Tishkov, A.A. 2012. The steppe biome in Russia: ecosystem services, conservation status, and actual challenges. In: Werger, M.J.A. \& van Staalduinen, M.A. (eds.) Eurasian steppes. Ecological problems and liveliboods in a changing world, pp. 45-102. Springer, Dordrecht, NL.

Stanyukovich, K.W. 1982. Rastitelnost [Vegetation]. In: Saidmuradow, C.M. \& Stanyukovich, K.W. (eds.) Tadzhikistan. Priroda i prirodnye resursy, pp. 358-435. Izdatelstvo Donish, Dushanbe, TJ. [in Russian]

Taft, J.B., Philippe, L.R., Dietrich, C.H. \& Robertson, K.R. 2011. Grassland composition, structure, and diversity patterns along major environmental gradients in the Central Tien Shan. Plant Ecology 212: 1349-1361.

Ter Braak, C.J.F. \& Šmilauer, P. 2002. CANOCO Reference Manual and CanoDraw for Windows User's guide: Software for Canonical Community Ordination (version 4.5). Microcomputer Power, Ithaca, New York, US.

Tichý, L. 2002. JUICE, software for vegetation classification. Journal of Vegetation Science 13: 451-453.

Walter, H. \& Box, E.O. 1983. Continental deserts and semideserts of Eurasia. In: West, N.E. (ed.). Temperate deserts and semi-deserts. Ecosystems of the World 5, pp. 3-319. Elsevier, Amsterdam, NL.

Walter, H. \& Breckle, S.-W. 1994. Ökologie der Erde, Vol. 3: Spezielle Ökologie der gemäßigten und arktischen Zonen Euro- und Nordasiens. Fischer, Stuttgart, DE. 
Werger, M.J.A. \& van Staalduinen, M.A. (eds.) 2012. Eurasian steppes. Ecological problems and liveliboods in a changing world. Springer, Dordrecht, NL.

Weber, H.E., Moravec, J. \& Theurillat, J.-P. 2000. International Code of Phytosociological Nomenclature. 3rd edition. Journal of Vegetation Science 11: 739-768.

Wesche, K., Ambarlı, D., Kamp, J., Török, P., Treiber, J. \& Dengler, J. 2016. The Palaearctic steppe biome: a new synthesis. Biodiversity and Conservation 25: 2197-2231.

Westhoff, V. \& van der Maarel, E. 1973. The Braun-Blanquet approach. Handbook of Vegetation Science 5: 619-726.

Willner, W., Kuzemko, A., Dengler, J., Chytrý, M., Bauer, N., Becker, T., Biţá-Nicolae, C., Botta-Dukát, Z., Čarni, A., (...) \& Janišová, M. 2016. A higher-level classification of the Pannonian and western Pontic steppe grasslands (Central and Eastern Europe). Applied Vegetation Science 20: 143-158.
Yunatov, A.A. 1946. Kratkiy ocherk rastitelnovo pokrova Mongolskoy Narodnoy Respubliki. [A brief summary of the plant cover of the Mongolian National Republic]. Uchonye Zapiski Mongolskovo Universiteta 1: 17-45. [in Russian]

Yunatov, A.A. 1974. Pustynnye stepi Severnoy Gobi w Mongolskoy Narodnoy Respublike. [Deserted steppes in northern Gobi in Mongolia National Republic]. Biolohicheskye resursy i prirodnye uslovya Mongolskoy Narodnoy Respubliki. Vol. 4. Nauka, Moscow, RU. [in Russian]

Zheng, J.G., Chen, Y.W. \& Wu, G.X. 2013. Association of vegetation patterns and environmental factors on the arid western slopes of the Helan Mountains. Mountain Research E Development 33: 323-331.

\section{Author addresses}

Nowak, A. (corresponding author, anowak@uni.opole.pl; orcid ID: 0000-0001-8638-0208)1,3, Nobis, A. (agnieszka.nobis@uj.edu. pl; orcid ID: 0000-0002-8318-8816)2, Nowak, S. (snowak@uni.opole.pl)33, Nobis, M. (m.nobis@uj.edu.pl)2

${ }^{1}$ Botanical Garden, Center for Biological Diversity Conservation, Polish Academy of Sciences, Prawdziwka 2, 02-976 Warszawa, Poland; anowak@uni.opole.pl

${ }^{2}$ Institute of Botany, Jagiellonian University, Kopernika 27, 31-501 Kraków, Poland

${ }^{3}$ Department of Biosystematics, Laboratory of Geobotany \& Plant Conservation, Opole University, Oleska 22, 45-052 Opole, Poland

\section{Electronic Supplement}

Supplementary material associated with this article is embedded in the article's pdt. The online version of Phytocoenologia is hosted at the journal's website www.schweizerbart.com/journals/phyto. The publisher does not bear any liability for the lack of usability or correctness of supplementary material.

Supplement S1. Analytic table of the Ajanio-Cleistogenetalia songoricae (Ajanio-Cleistogenetea songoricae).

Supplement S2. Analytic table of the Carici stenophylloidis-Stipetalia arabicae (Astragalo microcephali-Brometea tomentelli).

Supplement S3. Analytic table of the Stipetalia krylovii (Cleistogenetea squarrosae).

Supplement S4. Photo guide to the plant communities described in this article.

Please save the electronic supplement contained in this pdf-file by clicking the blue frame above. After saving rename the file extension to .zip (for security reasons Adobe does not allow to embed .exe, .zip, .rar etc. files). 